\title{
Analysis of Soil Quality Status and Accumulation of Potentially Toxic Element in Food Crops Growing at Fecal Sludge Dumpsite in Ubakala, Nigeria
}

\author{
Ogbonna P.C. ${ }^{1}{ }^{*}$, Okezie I.P. ${ }^{2}$, Onyeizu U.R. ${ }^{3}$, Biose E. ${ }^{4}$, Nwankwo O.U. ${ }^{5}$ and \\ Osuagwu E.C. ${ }^{6}$ \\ ${ }^{1,2,3,5,6}$ Department of Environmental Management and Toxicology, Michael Okpara University of Agriculture, \\ Umudike, Abia State, Nigeria \\ ${ }^{4}$ Department of Environmental Management and Toxicology, University of Benin, Edo State, Nigeria \\ Corresponding Author: *ogbonna_princewill@yahoo.com
}

https://doi.org/10.36263/nijest.2021.01.0273

\begin{abstract}
This study investigated the magnitude of potentially toxic element (PTE) in fecal sludge and the level of contamination of soil and food crops at Ubakala, Abia State, Nigeria. Soil samples were collected in four cardinal points at north $(N)$, south $(S)$, east (E) and west (W) of $1 \mathrm{~m}, 5 \mathrm{~m}, 15 \mathrm{~m}$ and $30 \mathrm{~m}$ from the edge of the fecal sludge dumpsite and standards (2 ppm, 4 ppm and 6 ppm) were prepared from 1000 ppm stock solution of the metals and used to plot the calibration curve with Atomic Absorption Spectrometer. Commonly consumed Carica papaya, Telfairia occidentalis and Manihot esculenta leaf samples were collected and analyzed to measure the concentrations of PTEs such as $\mathrm{Cd}, \mathrm{Zn} \mathrm{Cr}, \mathrm{Mn}, \mathrm{Pb}$ and $\mathrm{Cu}$. The concentrations of $\mathrm{Zn}(12.41 \pm 0.30 \mathrm{mg} / \mathrm{kg}), \mathrm{Cd}$ $(0.07 \pm 0.00 \mathrm{mg} / \mathrm{kg}), C r(4.47 \pm 0.34 \mathrm{mg} / \mathrm{kg}), C u(2.12 \pm 0.03 \mathrm{mg} / \mathrm{kg}), \mathrm{Mn}(8.13 \pm 0.03 \mathrm{mg} / \mathrm{kg})$ and $\mathrm{Pb}$ $(0.01 \pm 0.00 \mathrm{mg} / \mathrm{kg})$ in dried fecal sludge are below the permitted limits of European Union. Concentrations of PTEs in soil and plants were Zn $(13.40 \pm 1.20$ to $100.80 \pm 1.40$ and $1.24 \pm 0.06$ to $56.02 \pm 5.02 \mathrm{mg} / \mathrm{kg}), C d(0.07 \pm 0.01$ to $0.92 \pm 0.02$ and $0.0000 \pm 0.000$ to $0.085 \pm 0.01 \mathrm{mg} / \mathrm{kg}), C u$ $(6.27 \pm 0.31$ to $31.39 \pm 1.04$ and $0.002 \pm 0.001$ to $10.80 \pm 2.01 \mathrm{mg} / \mathrm{kg}), \mathrm{Mn}(36.00 \pm 1.56$ to $188.57 \pm 2.25$ and $0.11 \pm 0.00$ to $17.21 \pm 2.01 \mathrm{mg} / \mathrm{kg}), \mathrm{Cr}(2.40 \pm 0.40$ to $21.03 \pm 1.43$ and $0.000 \pm 0.00$ to $9.60 \pm 1.13$ $\mathrm{mg} / \mathrm{kg})$ and $\mathrm{Pb}(0.09 \pm 0.02$ to $0.35 \pm 0.03$ and $<0.00001 \pm 0.00$ to $0.008 \pm 0.00 \mathrm{mg} / \mathrm{kg})$, respectively. Zinc in soil is higher than FAO/WHO permissible limit while Cd in soil is higher than FAO/WHO limit and Dutch criteria for soil. Zinc and Cr in food crops are higher than FAO/WHO permissible limit. Strong positive relationship exist between $\mathrm{Zn}$ in soil and food crops $(r=0.616, p<0.05)$. Based on the findings, it is recommended that the fecal sludge should be treated with lime to precipitate PTE content of sludge and lowering the corresponding environmental risks.
\end{abstract}

Keywords: Fecal sludge, Soil quality, Food crops, Toxic elements, Ubakala

\subsection{Introduction}

Urban development in the last 30 to 40 years seems to have culminated to an increase in rural-urban migration in Nigeria, thus, increasing the population of people in urban areas. Urban development brings about an overall increase in the number of buildings by Landlords that are mostly occupied by tenants as well as some Landlords. The concomitant effect of sharp increase in number of tenants may result to an exponential inversely proportion on the generation of waste since people (i.e. the tenants) consume foods ranging from staples (garri, rice, yam etc.), fruits and vegetables (oranges, cucumber, carrots, pawpaw, spinach, bitter leaf, fluted pumpkin, waterleaf etc.) to can foods and takeaway. The foods eaten by the tenants digest in their alimentary system, and supply the body with the required nutrients while the rest are passed out from the body as feces. The fecal wastes are passed out into onsite sanitation system. An on-site sanitation system is defined as a system of sanitation where the means of storage are contained within the plot occupied by the dwelling and its immediate surroundings (WHO, 2006). In Sub-Saharan Africa, 65 to $100 \%$ of sanitation access in urban areas is provided through onsite technologies (Strauss et al., 2000). The on-site sanitation system gets filled 
up with feces over a period of years and are emptied into tankers (trucks) without treatment, transported and discharged into open drains, irrigation fields, open lands, or surface waters. According to Bassan et al. (2014), a $5 \mathrm{~m}^{3}$ truck load of fecal sludge dumped into the environment is the equivalent of 5,000 people practicing open defecation. The amount of untreated fecal sludge discharged into the open environment poses a serious financial and public health risk. For example, the World Bank estimates that poor sanitation costs the world 260 billion USD annually and contributes to 1.5 million child deaths from diarrhea each year. Fecal sludge contains various heavy metals and microorganisms which have potential ecological, biological and health impacts (Hashem, 2000).

Since Ubakala is located in South east Nigeria which experience heavy rainfall during the wet season, the fecal sludge may be leached into water bodies with its concomitant challenges. For instance, the United Nations reported that about 1.8 billion people globally use source of drinking water that is contaminated with feces (Zziwa et al., 2016). Currently one in five children die from diarrheal related diseases, which is more than that of HIV Aids, malaria, and measles combined (UNICEF and WHO, 2009) and chronic diarrhea hinder child development by impeding the absorption of essential nutrients that are critical to the development of the mind, body, and immune system (Strande et al., 2014). In furtherance of this, some proportion of the fecal sludge may contain heavy metals which is of great concern in the world. The accumulation of dissolved heavy metals in water is hazardous to water bodies and human health when their values are higher than the corresponding threshold (Pape et al., 2012; Varol et al., 2013; Bu et al., 2015; Ogbonna et al., 2020a).

Poor planning and ineffective implementation of laws and regulations for waste collection, treatment and disposal at various levels of Governance in Nigeria may have resulted to indiscriminate dumping of fecal sludge on terrestrial and aquatic ecosystems. As urbanization continues to take place, the management of fecal sludge is becoming a serious public health and environmental concern particularly in South east Nigeria. Fecal sludge from the on-site sanitation systems does not undergo treatment because there is no fecal sludge treatment plant in South east Nigeria. The technologies or technical options applied for fecal sludge treatment are categorized into established fecal sludge treatment technologies (co-composting, co-treatment in waste stabilization ponds, deep row entrenchment), transferred sludge treatment technologies (anaerobic digestion, lime addition, sludge incineration, mechanical sludge treatment) and innovative technologies (vermicomposting, black soldier fly, ammonia treatment) for fecal sludge treatment (Strande et al., 2014; Ackah, 2016). Poor fecal sludge management may have far reaching adverse impacts on the chemical characteristics of soil since the contents of fecal sludge may have the capacity to influence soil quality and possible accumulation of contaminants in plants. For instance, heavy metal is part of the constituents of fecal sludge (Hashem, 2000).

Plants growing on potentially toxic element (PTE) contaminated soil tend to absorb PTE such as heavy metals from soil solution via the roots and translocate it to the stems and the leaves (Ogbonna et al., 2018a; 2020a). The chemical form of potentially toxic element in soil can strongly influence their uptake by plants as mobile ions present in the soil solution through the roots resulting in bioaccumulation of the elements in plants tissues (Pitchell and Anderson, 1997; Davies, 1983; Amusan et al., 2005). The harvest of such plants at maturity, their sales at the farms or in the markets and subsequent consumption by man (including animals) may result to accumulation of heavy metals in the body. Some potentially toxic element such as copper $\mathrm{Cu}$, nickel (Ni), and zinc $(\mathrm{Zn})$ are essential at trace amount while lead $(\mathrm{Pb})$, cadmium $(\mathrm{Cd})$ and mercury $(\mathrm{Hg})$ are non-essential to living organisms. Consequently, the investigation of PTE in fluted pumpkin (Telfairia occidentalis Hook f.), pawpaw (Carica papaya Linn) and cassava (Manihot esculenta Crantz) growing at fecal sludge dumpsite is vital since these foodstuffs are important components of human diet. For instance, vegetables are rich in vitamins such as beta carotene, ascorbic acid, riboflavin, folic acid as well as minerals like iron, calcium, phosphorus, bioactive non-nutritive health promoting factors as antioxidants, phyto-chemicals, essential fatty acids and dietary fibre which are essential dietary constituents required for growth, development and reproduction (Gupta etal., 2008; Okonwu et al., 2018). It (vegetables) also supply alkaline substance in the body to maintain acid-base balance (Funke, 2011), serve as medicine to reducing the risk of chronic diseases (Gosslau and Chen, 2004; Lee et al., 2008) cancer, blood pressure and high cholesterol (Antonious et al., 2009). Carica papaya contains enzymes, minerals (Santana et al., 2019), phytochemicals such as polyphenols, phenols, 
flavonoids, carotenoid, Lycopene, betacarotinoid, benzylisothyocynate, betacryptoxanthin, benzylglucosinolate, chlorogenic acid, caffeic acid, protocatachuic acid, Quercetin and traditional antioxidant vitamins such as vitamin $\mathrm{C}$ and $\mathrm{E}$ (Pinnamaneni, 2017). It (pawpaw) also contain hymopapain and papain which are widely used for digestive disorders (Huet et al., 2006), antihelminthic and anti-amoebic (Okeniyi et al., 2007), while leaf decoction is administered as a purgative for horses and used for the treatment of genito-urinary system (Pinnamaneni, 2017). Cassava root is rich in carbohydrate, calcium, iron, potassium, magnesium, copper, zinc, and manganese comparable to many legumes (Montagnac et al., 2009).

This study aimed to determine the distribution of potentially toxic element (PTE) in soil and accumulation in food crops at fecal sludge dumpsite in Umuahia, Abia State, Nigeria and the result obtained were compared to permissible limits set by International Organizations and National Standards of some countries to ascertain the status of the fecal sludge as organic material and possible health implications of consuming food crops growing on the site.

\subsection{Materials and Methods}

\subsection{Study area}

The study was carried out in Ubakala in Umuahia South Local Government Area of Abia State, Nigeria (Figures 1 and 2). Ubakala is located in the lowland rainforest zone of Nigeria (Keay, 1959) and lies on latitude $5^{\circ} 26^{\prime}$ to $5^{\circ} 34^{\prime} \mathrm{N}$ and longitude $7^{\circ} 22^{\prime}$ to $7^{\circ} 33^{\prime} \mathrm{E}$. It experience two seasons viz the wet season that is characterized with heavy rainfall between April to November and short dry season from December to early March. The mean annual rainfall is $1,122 \mathrm{~mm}$, and annual relative humidity is over $65 \%$ while the mean annual temperature exceeds $27^{\circ} \mathrm{C}$.

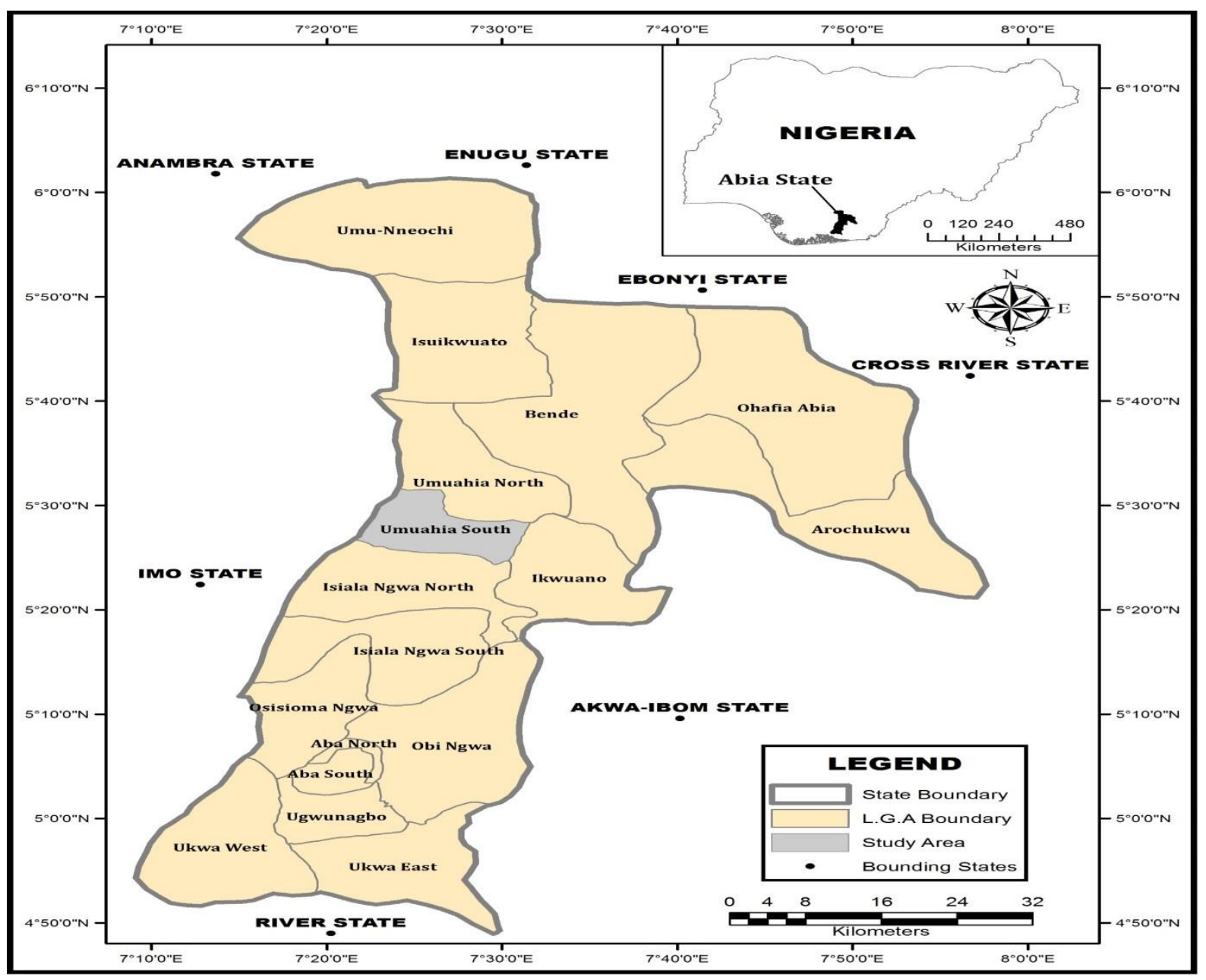

Figure 1: Abia State showing Umuahia South Source: Ogbonna et al. (2020a) 
The surface elevation is about $120 \mathrm{~m}$ and the area has low-lying to moderately high plain topography. It is drained by Imo River and its tributaries are perennial, resulting in secondary rainforest vegetation along the river banks. Agriculture is well practiced by the people and crops commonly grown include cassava, maize, fluted pumpkin, yam, okra, groundnut, pawpaw, oil palm trees, cola nuts, cocoa while animals such as poultry birds, pigs, goats, snails are raised.

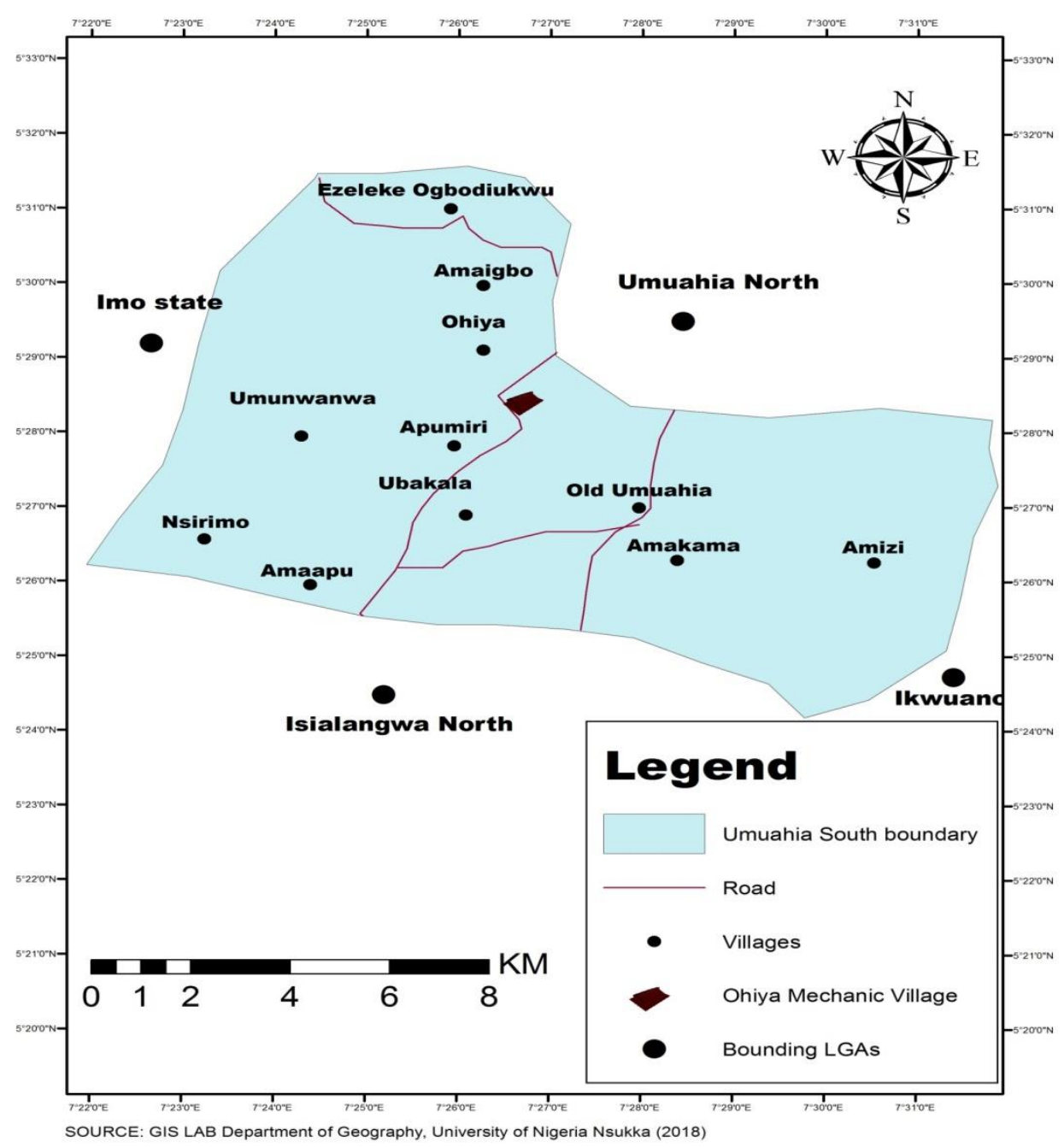

Figure 2: Map of study area

\subsection{Sample collection}

\subsubsection{Collection of fecal sludge samples}

The experiment was preceded by a visit to the fecal sludge dumpsite area. The purpose of the visit was to learn the history of the fecal sludge dumpsite, identify the food crops that were common in the study site, the various distances the food crops were growing at the four cardinal points from the edge of the fecal sludge dumpsite as well as the terrain of the site (which is table in nature). Fecal samples were collected with steel core sampler to the depth of $1 \mathrm{~m}$ from ten (10) different sampling points in four cardinal points (i.e. two sampling points each at north $(\mathrm{N})$, south (S), east (E), west (W), and at the center $(\mathrm{C})$ of the fecal sludge dumpsite. The steel core sampler was cleaned with deionized water for each individual sample collection to avoid cross-contamination. The samples from N, S, E, W and $\mathrm{C}$ were bulked together to form a composite sample and placed (about $160 \mathrm{~g}$ ) in large ASEPA polythene bags, well-sealed, labeled, placed in a wooden box and covered to avoid contamination from external sources. The samples in the wooden box were transferred to the laboratory for pretreatment and analysis. The fecal samples were air-dried at room temperature until all moisture was completely eliminated. The sample was subjected to crushing and grinding and then homogenized using a porcelain pestle and mortar. The homogenized fecal samples were sieved $(0.2 \mathrm{~mm})$ and stored in refrigerator prior to digestion. The sample were analyzed for $\mathrm{pH}$, organic matter, nitrogen $(\mathrm{N})$, 
phosphorus $(\mathrm{P})$, potassium $(\mathrm{K})$, calcium $(\mathrm{Ca})$, sodium $(\mathrm{Na})$, magnesium $(\mathrm{Mg})$, and potentially toxic elements chromium $(\mathrm{Cr})$, copper $(\mathrm{Cu})$, cadmium $(\mathrm{Cd})$, zinc $(\mathrm{Zn})$, lead $(\mathrm{Pb})$, and manganese $(\mathrm{Mn})$ using standard laboratory methods.

\subsubsection{Collection of soil samples}

Surface soil $(0-20 \mathrm{~cm})$ samples were collected from eight (8) different points with thoroughly cleaned Dutch soil auger in four cardinal points (i.e. two sampling points each at north $(\mathrm{N})$, south (S), east (E) and west $(\mathrm{W})$ of $1 \mathrm{~m}, 5 \mathrm{~m}, 15 \mathrm{~m}$ and $30 \mathrm{~m}$ from the edge of the fecal sludge dumpsite in September 2019. The Dutch soil auger was cleaned with deionized water for each individual sample collection to avoid cross-contamination. The control sample was collected in a 2 year upland bush fallow about 1 $\mathrm{km}$ from the dumpsite where there was no visible source of contamination. Soil samples from the same distance (e.g. 0-20 cm depth from $1 \mathrm{~m}$ at N, S, E and W) were bulked together to form a composite sample and placed in large polythene bags (about $80 \mathrm{~g}$ ), well-sealed, labeled, placed in a wooden box and covered to avoid contamination from external sources. The samples in the wooden box were transferred to the laboratory for pre-treatment and analysis. Each bulked soil sample was freed from roots, stones, and seeds and air-dried at room temperature until all moisture was completely eliminated. The samples were crushed, ground to increase the surface area for chemical reactions and homogenized using a porcelain pestle and mortar. The homogenized soil samples were sieved $(<2 \mathrm{~mm})$ and analyzed for $\mathrm{pH}$, organic matter, electrical conductivity (EC) and potentially toxic elements $(\mathrm{Cr}, \mathrm{Cu}, \mathrm{Cd}, \mathrm{Zn}, \mathrm{Pb}$ and $\mathrm{Mn})$ using standard laboratory methods.

\subsubsection{Collection of plants samples}

Fresh leaves were sampled from eight stands each of Carica papaya Linn. (pawpaw, Caricaceae), Telfairia occidentalis Hook f. (fluted pumpkin, Cucurbitaceae) and Manihot esculenta Crantz (cassava or manioc, Euphorbiaceae) at each particular distance. For example, two (2) stands of pawpaw were collected each at N, S, E and W). The leaves were randomly collected in September 2019 from different parts of each plant species using thoroughly cleaned secateurs. These three plant species were sampled because they were common among all sampling distance, thus, the plants were growing around the points where soil samples were collected from the fecal sludge dumpsite. Samples from each plant species was placed separately in large envelopes, labeled well and sealed, placed in a wooden box and covered to avoid contamination from external sources. The samples in the wooden box were transferred to the laboratory for pre-treatment and analysis.

\subsubsection{Analysis of potentially toxic element in plant samples}

The leaves were thoroughly rinsed with deionized water to remove adhered soil, dust and pollen particles and placed in large crucibles and oven dried at $60^{\circ} \mathrm{C}$ for 96 hours. The dried leaves samples was milled to fine powder $(<1 \mathrm{~mm})$ using a cyclone sample mill (model 3010-019). The analysis was carried out using the procedure of Yeketetu (2017). About $0.5 \mathrm{~g}$ of each of the plant samples were weighed separately into a digestion flask and digested in furnace at $500{ }^{\circ} \mathrm{C}$ for four hours, and then 10 $\mathrm{ml}$ of $6 \mathrm{M} \mathrm{HCl}$ were added, covered and heated on a steam bath for 15 minute in fume hood. Another $1 \mathrm{ml}$ of $\mathrm{HNO}_{3}$ was added and evaporated to dryness by continuous heating for one hour to dehydrate silica and completely digest organic compounds. Finally, $5 \mathrm{ml}$ of $6 \mathrm{M} \mathrm{HCl}$ and $10 \mathrm{ml}$ of water were added and the mixture was heated on a steam bath to complete dissolution. The mixture was cooled, filtered into a $50 \mathrm{~mL}$ volumetric flask and made up to the mark with distilled water (Singh et al., 2010). Then the samples were analyzed for potentially toxic element $(\mathrm{Cr}, \mathrm{Cu}, \mathrm{Cd}, \mathrm{Zn}, \mathrm{Pb}$ and $\mathrm{Mn}$ ) using Atomic Absorption Spectrometer (model AA-7000 Shimadzu, Japan).

2.2.5. Analysis of exchangeable bases, organic matter, EC in fecal samples and potentially toxic element in soil and fecal sludge

The procedures of Adeyeye (2005) and Bhowmick et al. (2013) was adopted with modifications. One (1) $\mathrm{g}$ of the sieved samples were weighed into digestion flask and $30 \mathrm{~cm}^{3}$ of aqua regia was added and digested in a fume-cupboard until clear solution was obtained, which was cooled, filtered and then made up to $50 \mathrm{ml}$ mark in a standard volumetric flask with de-ionized water. A blank sample was prepared to zero the instrument before running other series of samples. Standards (2 ppm, $4 \mathrm{ppm}$ and $6 \mathrm{ppm}$ ) were prepared from $1000 \mathrm{ppm}$ stock solution of the metals and used to plot the calibration curve. The curve was plotted automatically by the instrument. Exactly $0.2 \mathrm{~g}$ was pipette from 1000 
ppm, pour into $100 \mathrm{ml}$ flask and made to the mark with deionized water. This procedure was used in the preparation of $4 \mathrm{ppm}$ and $6 \mathrm{ppm}$, respectively. High temperature was produced in the ignition chamber and provided enhanced reducing settings for the atomization of the respective metals/minerals. Each standard was aspirated by nebulizer, converted into an aerosol, mixed with the gases and converted into atomic form. All the standard solutions were analyzed and the calibration curve was plotted automatically for the metals/minerals of interest. Each metal/mineral $(\mathrm{Pb}, \mathrm{Mn}, \mathrm{Zn}$, $\mathrm{Cr}, \mathrm{Cu}, \mathrm{Cd}, \mathrm{K}, \mathrm{Na}, \mathrm{Ca}$ and $\mathrm{Mg}$ ) were analyzed using its respective wavelength after which its concentration was generated from the standard graph by the instrument (Atomic Absorption Spectrometer, model AA-7000 Shimadzu, Japan). Triplicate digestion of each sample was carried out together with blank digest without the sample. The measuring conditions of $\mathrm{Pb}, \mathrm{Mn}, \mathrm{Zn}, \mathrm{Cr}, \mathrm{Cu}, \mathrm{Cd}$, $\mathrm{K}, \mathrm{Na}, \mathrm{Ca}$ and $\mathrm{Mg}$ ions are as follows:

Pb: Burner height: $8.0 \mathrm{~mm}$; Wave length: $283.3 \mathrm{~nm}$; Burner angle: 0 degree; Slit width: $0.7 \mathrm{~nm}$; Fuel gas flow rate: $2.3 \mathrm{~L} / \mathrm{min}$; Lighting mode: $\mathrm{BGC}-\mathrm{D} 2$; Flame type: air- $\mathrm{C}_{2} \mathrm{H}_{2}$. A five point's calibration curve is made with $0,0.1 \mathrm{ppm}, 0.2 \mathrm{ppm}, 0.4 \mathrm{ppm}, 0.6 \mathrm{ppm}$ standard solutions prepared from certified 1000 ppm standard solution.

Mn: Burner height: $7.0 \mathrm{~mm}$; wave length: $279.5 \mathrm{~nm}$; Burner angle: 0 degree; Slit width: $0.2 \mathrm{~nm}$; Fuel gas flow rate: $2.0 \mathrm{~L} / \mathrm{min}$; Lighting mode: BGC-D2; Flame type: air- $\mathrm{C}_{2} \mathrm{H}_{2}$. A five point's calibration curve is also made with $0,0.1 \mathrm{ppm}, 0.2 \mathrm{ppm}, 0.3 \mathrm{ppm}, 0.4 \mathrm{ppm}$ standard solutions prepared from certified 1000 ppm standard solution.

Zn: Burner height: $7.0 \mathrm{~mm}$; Wave length: $213.9 \mathrm{~nm}$; Burner angle: 0 degree; Slit width: $0.7 \mathrm{~nm}$; Fuel gas flow rate: $2.0 \mathrm{~L} / \mathrm{min}$; Lighting mode: $\mathrm{BGC}-\mathrm{D} 2$; Flame type: air- $\mathrm{C}_{2} \mathrm{H}_{2}$. A five point's calibration curve is also made with $0,0.1 \mathrm{ppm}, 0.2 \mathrm{ppm}, 0.4 \mathrm{ppm}, 0.8 \mathrm{ppm}$ standard solutions prepared from certified $1000 \mathrm{ppm}$ standard solution.

Cr: Burner height: $7 \mathrm{~mm}$; Wave length: $766.5 \mathrm{~nm}$; Burner angle: 0 degree; Slit width: $0.5 \mathrm{~nm}$; Fuel gas flow rate: $2.0 \mathrm{~L} / \mathrm{min}$; Lighting mode: $\mathrm{BGC}-\mathrm{D} 2$; Flame type: air- $\mathrm{C}_{2} \mathrm{H}_{2}$. A five point's calibration curve is also made with $0,0.1 \mathrm{ppm}, 0.2 \mathrm{ppm}, 0.4 \mathrm{ppm}, 0.8 \mathrm{ppm}$ standard solutions prepared from certified $1000 \mathrm{ppm}$ standard solution. Moreover, same volume of 0.1 to $0.2 \%$ cesium chloride is added to the standard and unknown sample to prevent the ionization of potassium.

Cu: Burner height: $7 \mathrm{~mm}$; Wave length: $766.5 \mathrm{~nm}$; Burner angle: 0 degree; Slit width: $0.5 \mathrm{~nm}$; Fuel gas flow rate: 2.0 1/min; Lighting mode: BGC-D2; Flame type: air- $\mathrm{C}_{2} \mathrm{H}_{2}$. A five point's calibration curve is also made with $0,0.1 \mathrm{ppm}, 0.2 \mathrm{ppm}, 0.4 \mathrm{ppm}, 0.8 \mathrm{ppm}$ standard solutions prepared from certified $1000 \mathrm{ppm}$ standard solution. Moreover, same volume of 0.1 to $0.2 \%$ cesium chloride is added to the standard and unknown sample to prevent the ionization of potassium.

Cd: Burner height: $7 \mathrm{~mm}$; Wave length: $766.5 \mathrm{~nm}$; Burner angle: 0 degree; Slit width: $0.5 \mathrm{~nm}$; Fuel gas flow rate: 2.0 1/min; Lighting mode: $\mathrm{BGC}-\mathrm{D} 2$; Flame type: air- $\mathrm{C}_{2} \mathrm{H}_{2}$. A five point's calibration curve is also made with $0,0.1 \mathrm{ppm}, 0.2 \mathrm{ppm}, 0.4 \mathrm{ppm}, 0.8 \mathrm{ppm}$ standard solutions prepared from certified $1000 \mathrm{ppm}$ standard solution. Moreover, same volume of 0.1 to $0.2 \%$ cesium chloride is added to the standard and unknown sample to prevent the ionization of potassium.

K: Burner height: $7.0 \mathrm{~mm}$; Wave length: $766.5 \mathrm{~nm}$; Burner angle: 0 degree; Slit width: $0.7 \mathrm{~nm}$; Fuel gas flow rate: $2.0 \mathrm{~L} / \mathrm{min}$; Lighting mode: NON-BGC; Flame type: air- $\mathrm{C}_{2} \mathrm{H}_{2}$. A five point's calibration curve is also made with $0,0.1 \mathrm{ppm}, 0.2 \mathrm{ppm}, 0.4 \mathrm{ppm}, 0.8 \mathrm{ppm}$ standard solutions prepared from certified $1000 \mathrm{ppm}$ standard solution. Moreover, same volume of 0.1 to $0.2 \%$ cesium chloride is added to the standard and unknown sample to prevent the ionization of potassium.

Na: Burner height: $7.0 \mathrm{~mm}$; wave length: $589.0 \mathrm{~nm}$; Burner angle: 0 degree; Slit width: $0.2 \mathrm{~nm}$; Fuel gas flow rate: $1.8 \mathrm{~L} / \mathrm{min}$; lighting mode: NON-BGC; Flame type: air- $\mathrm{C}_{2} \mathrm{H}_{2}$. A five point's calibration curve is also made with $0,0.1 \mathrm{ppm}, 0.2 \mathrm{ppm}, 0.3 \mathrm{ppm}, 0.4 \mathrm{ppm}$ standard solutions prepared from certified $1000 \mathrm{ppm}$ standard solution.

Ca: Burner height: $17 \mathrm{~mm}$; Wave length: $422.7 \mathrm{~nm}$; Burner angle: 0 degree; Slit width: $0.7 \mathrm{~nm}$; Fuel gas flow rate: $2.0 \mathrm{~L} / \mathrm{min}$; Lighting mode: BGC-D2; Flame type: air- $\mathrm{C}_{2} \mathrm{H}_{2}$. A five point's calibration 
curve is made with $0,0.1 \mathrm{ppm}, 0.2 \mathrm{ppm}, 0.4 \mathrm{ppm}, 0.6 \mathrm{ppm}$ standard solutions prepared from certified $1000 \mathrm{ppm}$ standard solution. However, it is ionized and 0.1 to $0.2 \%$ potassium chloride is added to the standard and unknown sample with same extent.

Mg: Burner height: $7 \mathrm{~mm}$; Wave length: $285.2 \mathrm{~nm}$; Burner angle: 0 degree; Slit width: $0.7 \mathrm{~nm}$; Fuel gas flow rate: $1.8 \mathrm{~L} / \mathrm{min}$; Lighting mode: $\mathrm{BGC}-\mathrm{D} 2$; Flame type: air- $\mathrm{C}_{2} \mathrm{H}_{2}$. A five point's calibration curve is also made with $0,0.1 \mathrm{ppm}, 0.2 \mathrm{ppm}, 0.4 \mathrm{ppm}, 0.8 \mathrm{ppm}$ standard solutions prepared from certified 1000 ppm standard solution.

\subsubsection{Determination of nitrogen}

Nitrogen was determined by the micro-Kjedahl method as described in Pearson (1976). The $1 \mathrm{~g}$ of the ground samples was weighed into the $500 \mathrm{ml} \mathrm{Kjedahl} \mathrm{digestion} \mathrm{flask} \mathrm{(Barloworld} \mathrm{UK,} \mathrm{model} \mathrm{Fk}$ $500 / 31)$. The $1 \mathrm{~g}$ of catalyst mixture (20 g potassium sulphate, $1 \mathrm{~g}$ copper sulphate and $0.1 \mathrm{~g}$ selenium powder) was weighed and added into the flask, and $15 \mathrm{ml}$ of conc. $\mathrm{H}_{2} \mathrm{SO}_{4}$ was also added. Heating was carried out cautiously on a digestion rack in a fume cupboard until a greenish clear solution appeared. The digest was allowed to clear for about 30 minute and allowed to cool. Ten (10) $\mathrm{ml}$ of distilled water was added to avoid caking. Then the digest was transferred with several washings into a $100 \mathrm{ml}$ volumetric flask and made up to the mark with distilled water. A $10 \mathrm{ml}$ aliquot was collected from the digest and placed in the flask. A $100 \mathrm{ml}$ receiver flask containing $5 \mathrm{ml}$ boric acid indicator solution was placed under the condenser of the distillation apparatus so that the tip was $2 \mathrm{~cm}$ inside the indicator. Ten (10) $\mathrm{ml}$ of $40 \% \mathrm{NaOH}$ solution was added to the digested sample through a funnel stop cork. The distillation commenced by closing the system jet arm of the distillation apparatus. The distillate was collected in the receiver flask $(35 \mathrm{ml})$. Titration was carried out with $0.01 \mathrm{M}$ standard $\mathrm{HCl}$ to first pink colour. Triplicate digestion of each sample was carried out together with blank digest without the sample.

$\%$ Nitrogen wt. of sample $=\frac{\text { Titration vol. } \times 0.014 \times M \times 100 \times 50}{10}$

where $M=$ molarity of std. $\mathrm{HCl}$

\subsubsection{Determination of phosphorus}

Phosphorus (P) was determined by the Vanodo-molybdate spectrophotometric method using Shimadzu UV-Visible Spectrophotometer UV1800, Japan. About 3.0 to $3.2 \mathrm{~g}$ of samples to the nearest $0.001 \mathrm{~g}$ were weighed into vijcor crucible. A $0.5 \mathrm{~g}$ zinc oxide was added and the mixture was heated slowly on hot plate until the sample thickens, then the heating was slowly increased until the mass is completely charred. The crucibles were placed in muffle furnace at $550-600{ }^{\circ} \mathrm{C}$ and held for 2 hours before it was removed and cooled to room temperature. The $5 \mathrm{ml}$ each of distilled water and hydrochloric acid were added to the ash and the crucibles were covered with watch glasses and heated to gentle boiling for 5 minute and the solution were filtered into $100 \mathrm{ml}$ volumetric flasks. The inside of the watch glass and the sides of the crucibles were washed with $5 \mathrm{ml}$ of hot distilled water using wash bottle with fine jet. The crucibles and the filter papers were washed with four additional $5 \mathrm{ml}$ portions of hot distilled water and the solution was cooled to room temperature and neutralize to a faint turbidity by drop-wise addition of $50 \%$ potassium hydroxide solution. A $0.5 \mathrm{~N}$ hydrochloric acid was added drop-wise until the zinc oxide precipitate is dissolved. Then 2 additional drops was added and diluted to volume with distilled water and thoroughly mixed. About $10 \mathrm{ml}$ of the solution was pipette into clean dry $50 \mathrm{ml}$ volumetric flask and $8.0 \mathrm{ml}$ of hydrazine sulphate solution and $2.0 \mathrm{ml}$ of sodium molybdate solution were added. The flask was stopper and inverted 2 to 3 times, thereafter the stopper was loosen and heat for 10-15 minute in a vigorous boiling water bath. The bath was removed and cools to $25 \pm 5{ }^{\circ} \mathrm{C}$ in water bath and the volume was diluted with distilled water and thoroughly mixed. The solution was transferred to clean, dry cuvette and the transmittance was measured at 650 $\mathrm{ml}$ with the instrument adjusted to read $100 \%$ transmittance for a cuvette containing water. Reagent blanks were prepared using the procedure described with no samples. The phosphorus content of the samples and blanks were read from the transmittance graph.

Phosphorus $=\frac{10(A-B)}{W_{v}}$ 
where:

A $=$ phosphorus content of the sample aliquot

$\mathrm{B}=$ phosphorus content of the blank aliquot

$\mathrm{W}=$ weight of sample

$\mathrm{V}=$ volume of aliquot

\subsubsection{Determination of $\mathrm{pH}$}

The term $\mathrm{pH}$ is used to measure the amount of hydrogen ion concentration $\left(\mathrm{H}^{+}\right)$of a solution. It is, therefore, described as a measure of the acidity or alkalinity of the solution. The $\mathrm{pH}$ meter (Jenway $\mathrm{pH}$ meter, model 3510 USA) was standardized with $\mathrm{pH} \mathrm{4,} 7$ and 10 buffer solutions. It was then washed with distilled water, wiped and immersed in the samples (soil and fecal) and retained for a short while until the readings stabilized. The readings were then recorded from the display. The readings were taken in triplicates.

\subsubsection{Determination of organic matter}

Organic matter levels in the sieved soil and fecal samples were estimated indirectly from organic carbon (C) using the Walkley and Black procedure (Walkley and Black, 1934). Exactly $1 \mathrm{~g}$ of the finely ground samples were weighed separately into $500 \mathrm{ml}$ conical flasks. A $10 \mathrm{ml}$ of $1 \mathrm{M}$ potassium dichromate was poured inside the flasks and the mixture was swirled. Then $20 \mathrm{ml}$ of conc. $\mathrm{H}_{2} \mathrm{SO}_{4}$ was added and the flasks were swirled again for 1 minute in a fume cupboard. The mixture were allowed to cool for 30 minutes after which $200 \mathrm{ml}$ of distilled water, $1 \mathrm{~g} \mathrm{NaF}$ and $1 \mathrm{ml}$ of diphenylamine indicator were added. The mixtures were swirled and titrated with ferrous ammonium sulphate. The blanks were also treated in the same way. Triplicate digestion of each sample was carried out together with blank digest without the sample.

$\%$ Carbon $=\frac{(B-T) \times M \times 1.33 \times 0.003 \times 100}{g}$

where:

$\mathrm{B}=$ Titration volume (Blank)

$\mathrm{T}=$ Titration volume (Sample)

$\mathrm{M}=$ Molarity of $\mathrm{Fe}$ solution

Organic matter $=$ Organic carbon $\times 1.724$

\subsubsection{Quality assurance}

Triplicate digestion of each sample was carried out and blanks were prepared from only reagents without sample to check for background contamination by the reagents. Appropriate quality assurance procedures and precautions were taken to ensure the reliability of the results in all fecal sludge, soil and plant sample test. Samples were carefully handled to avoid cross-contamination. All Glass wares used were soaked into $3 \mathrm{M} \mathrm{HNO}_{3}$ overnight and washed with deionized water to reduce the chances of interferences, and reagents used were of analytical grades. Distilled and deionized water were used throughout the study.

The comparison and interpretation of the results of analyzed fecal sludge, soils and food crops is based on the control values, permissible limits established by Codex Alimentarius Commission (WHO/FAO), National standards of different countries and related studies.

\subsection{Results}

\subsection{Potentially toxic element in dried fecal sludge}

The concentration of potentially toxic element in dried fecal sludge is summarized in Table 1 . The result indicate that the six (6) potentially toxic element tested in this study were present in the fecal sludge. The concentrations of PTE in the dried fecal matter were Zn $(12.41 \pm 0.30 \mathrm{mg} / \mathrm{kg}), \mathrm{Cd}$ $(0.07 \pm 0.00 \mathrm{mg} / \mathrm{kg}), \mathrm{Cr}(4.47 \pm 0.34 \mathrm{mg} / \mathrm{kg}), \mathrm{Cu}(2.12 \pm 0.03 \mathrm{mg} / \mathrm{kg}), \mathrm{Mn}(8.13 \pm 0.03 \mathrm{mg} / \mathrm{kg})$ and $\mathrm{Pb}$ $(0.01 \pm 0.00 \mathrm{mg} / \mathrm{kg})$. The concentration of $\mathrm{Zn}$ in the dried fecal sample was $\mathrm{Zn}$ is $12.41 \pm 0.30 \mathrm{mg} / \mathrm{kg}$, which is well below the accepted limits of 500 and $1200 \mathrm{mg} / \mathrm{kg}(\mathrm{Zn})$ set by China (GB 4284-1984 and 
GB 4284-2018), respectively, 2500-4000 mg/kg (Zn) by the European Union (Directive 86/278/EEC) and $800 \mathrm{mg} / \mathrm{kg}(\mathrm{Zn})$ in Sweden (Chen et al., 2003) (Table 2). The concentration of $\mathrm{Zn}(12.41 \pm 0.30$ $\mathrm{mg} / \mathrm{kg}$ ) from fecal sludge dumpsite at Ubakala, Nigeria is higher than 0.058 to $0.094 \mathrm{mg} / \mathrm{kg}$ in fecal sludge at Accra region of Ghana (Ahmed et al., 2019). The concentration of $\mathrm{Cd}$ in the dried fecal sample was $0.07 \pm 0.00 \mathrm{mg} / \mathrm{kg}$, which is well below the accepted limits of $5 \mathrm{mg} / \mathrm{kg}$ and $3 \mathrm{mg} / \mathrm{kg}$ set by China (GB 4284-1984 and GB 4284-2018), respectively, 20-40 mg/kg (Cd) by the European Union (Directive 86/278/EEC) and $2 \mathrm{mg} / \mathrm{kg}$ (Cd) in Sweden (Chen et al., 2003) (Table 2). The concentration of $\mathrm{Cd}(0.07 \pm 0.00 \mathrm{mg} / \mathrm{kg})$ in fecal sludge dumpsite at Ubakala, Nigeria is well below 0.90 to 112.03 $\mathrm{mg} / \mathrm{kg}$ in sludge from municipal and industrial wastewater treatment plants in China (Wang and Mulligan, 2005), 0.8 to $7.3 \mathrm{mg} / \mathrm{kg}$ in dried sewage sludge in Greece (Spanos et al., 2016), 1.17 \pm 0.19 to $1.71 \pm 0.29 \mu \mathrm{g} / \mathrm{g}$ in sludge from wastewater treatment plants of Sparta and Kavala, Greece (Angelidis and Aloupi, 1999).

Table 1: Heavy metal concentration in dried fecal matter

\begin{tabular}{lc}
\hline Potentially toxic element & Concentration \\
\hline $\mathrm{pH}$ & $8.90 \pm 3.10$ \\
Organic matter $(\mathrm{OM})$ & $7.41 \pm 2.01 \%$ \\
$\mathrm{~N}$ & $0.06 \pm 0.02$ \\
$\mathrm{P}$ & $0.02 \pm 0.00 \mathrm{mg} / \mathrm{kg}$ \\
$\mathrm{K}$ & $0.47 \pm 0.01 \mathrm{cmol} / \mathrm{kg}$ \\
$\mathrm{Ca}$ & $0.03 \pm 0.00 \mathrm{cmol} / \mathrm{kg}$ \\
$\mathrm{Mg}$ & $0.05 \pm 0.00 \mathrm{cmol} / \mathrm{kg}$ \\
$\mathrm{Na}$ & $0.78 \pm 0.01 \mathrm{cmol} / \mathrm{kg}$ \\
$\mathrm{Cd}$ & $0.07 \pm 0.00 \mathrm{mg} / \mathrm{kg}$ \\
$\mathrm{Zn}$ & $12.41 \pm 0.30 \mathrm{mg} / \mathrm{kg}$ \\
$\mathrm{Cr}$ & $4.47 \pm 0.34 \mathrm{mg} / \mathrm{kg}$ \\
$\mathrm{Cu}$ & $2.12 \pm 0.03 \mathrm{mg} / \mathrm{kg}$ \\
$\mathrm{Mn}$ & $8.13 \pm 0.03 \mathrm{mg} / \mathrm{kg}$ \\
$\mathrm{Pb}$ & $0.01 \pm 0.00 \mathrm{mg} / \mathrm{kg}$ \\
\hline Values are mean \pm standard deviation of 3 replicates
\end{tabular}

The concentration of $\mathrm{Cu}$ in the dried fecal sample was $\mathrm{Cu}$ is $2.12 \pm 0.03 \mathrm{mg} / \mathrm{kg}$, which is well below the accepted limits of $500 \mathrm{mg} / \mathrm{kg}(\mathrm{Cu})$ in China (GB 4284-2018), $1000-1750 \mathrm{mg} / \mathrm{kg}(\mathrm{Cu})$ by the European Union (Directive 86/278/EEC) and $600 \mathrm{mg} / \mathrm{kg}$ in Sweden (Chen et al., 2003) (Table 2). The concentration of $\mathrm{Cu}(2.12 \pm 0.03 \mathrm{mg} / \mathrm{kg})$ in fecal sludge dumpsite at Ubakala, Nigeria is well below 120.31 to $2051.26 \mathrm{mg} / \mathrm{kg}$ (Wang and Mulligan, 2005), 51.0 to $198 \mathrm{mg} / \mathrm{kg}$ (Spanos et al., 2016), $78.7 \pm 6.5$ to $141.7 \pm 6.6 \mu \mathrm{g} / \mathrm{g}$ (Angelidis and Aloupi, 1999) but higher than 0.018 to $0.030 \mathrm{mg} / \mathrm{kg}$ (Ahmed et al., 2019).

The concentration of $\mathrm{Mn}$ in the dried fecal sludge was $8.13 \pm 0.03 \mathrm{mg} / \mathrm{kg}$, which is below $122.2 \pm 82.0$ to $251.0 \pm 115.6 \mathrm{mg} / \mathrm{kg}$ in pilot-scale sludge drying reed beds (Stefanakis and Tsihrintzis, 2012). The level of $\mathrm{Mn}$ in the fecal sludge suggests that its application in soil will enhance $\mathrm{Mn}$ in soil and subsequent assimilation in plants. The concentration of $\mathrm{Cr}$ in the dried fecal sample was $4.47 \pm 0.34$ $\mathrm{mg} / \mathrm{kg}$ which is wellbelow the permitted limits of $600 \mathrm{mg} / \mathrm{kg}$ (GB 4284-1984) and $500 \mathrm{mg} / \mathrm{kg}$ (GB 4284-2018) (Cr) established by China and $100 \mathrm{mg} / \mathrm{kg}$ (Cr) in Sweden (Chen et al., 2003) (Table 2).

Table 2: Limit values for heavy-metal concentrations in sludge for use in agriculture ( $\mathrm{mg} / \mathrm{kg}$ of dry

\begin{tabular}{|c|c|c|c|c|c|c|c|}
\hline Standard by country & $\mathrm{pH}$ & $\mathrm{Cd}$ & $\mathrm{Cu}$ & $\mathrm{Pb}$ & $\mathrm{Cr}$ & $\mathrm{Zn}$ & $\mathrm{Mn}$ \\
\hline \multirow[t]{3}{*}{ GB 4284-1984 (China) } & $\mathrm{pH}<6.5$ & 5 & 250 & 300 & 600 & 500 & NA \\
\hline & $\mathrm{pH} \geq 6.5$ & 20 & 500 & 1000 & 1000 & 1000 & NA \\
\hline & Grade A & 3 & 500 & 300 & 500 & 1200 & NA \\
\hline GB 4284-2018 (China) & Grade B & 15 & 1500 & 1000 & 1000 & 3000 & NA \\
\hline 40 CFR Part 503 (US) & & 85 & 4300 & 840 & NA & 7500 & NA \\
\hline Directive 86/278/EEC (EU 1986) & & $20-40$ & $1000-1750$ & $750-1200$ & NA & $2500-4000$ & NA \\
\hline (Sweden) (Chen et al., 2003) & & 2 & 600 & 100 & 100 & 800 & NA \\
\hline AbfKlaeV (Germany) & & 10 & 800 & 900 & 900 & 2500 & NA \\
\hline EU $3^{\text {rd }}$ Draft $(2000)$ & & 10 & 1000 & 750 & 1000 & 2500 & NA \\
\hline Greek Legislation 80568/4225/91 (1991) & & $20-40$ & $1000-1750$ & $750-1200$ & $* 510$ & $2500-4000$ & NA \\
\hline
\end{tabular}

The concentration of $\mathrm{Cr}(4.47 \pm 0.34 \mathrm{mg} / \mathrm{kg})$ in samples of fecal sludge dumpsite in Ubakala, Nigeria is higher than 0.00 to $<0.01 \mathrm{mg} / \mathrm{kg}$ in Accra region of Ghana (Ahmed et al., 2019). 
The concentration of $\mathrm{Pb}$ in the dried fecal sludge was $0.01 \pm 0.00 \mathrm{mg} / \mathrm{kg}$, which is well below the permitted limits of $300 \mathrm{mg} / \mathrm{kg}(\mathrm{Pb})$ set by China (GB 4384-2018), 750-1200 mg/kg (Pb) by the European Union (Directive 86/278/EEC) and $100 \mathrm{mg} / \mathrm{kg}(\mathrm{Pb})$ in Sweden (Chen et al., 2003). The concentration of $\mathrm{Pb}(0.01 \pm 0.00 \mathrm{mg} / \mathrm{kg})$ in samples of fecal sludge dumpsite in Ubakala, Nigeria is higher than 0.002 to $0.010 \mathrm{mg} / \mathrm{kg}$ (Ahmed et al., 2019). The concentrations of PTE in the dried fecal matter were below the permissible limits established by European Union, China and Sweden. The low concentration of PTEs in fecal sludge at Ubakala, Nigeria may be attributed to inadequate manufacturing of agricultural input (e.g. inorganic fertilizer, pesticides among others) for crop production in Nigeria unlike the developed countries. Thus, reducing the level of soil contamination by PTEs and uptake by food crops consumed by the people. Thus, the fecal sludge could be harnessed by farmers as organic material to boost crop yield. Consequently, there is need for periodic monitoring of PTE in soil to ascertain their (PTE) status in line with permitted limits set by countries in Europe, China, USA as well as International and National Organizations. Generally, the order of abundance of the potentially toxic element in the dried fecal matter from the fecal sludge dumpsite at Ubakala, Nigeria is: $\mathrm{Zn}>\mathrm{Mn}>\mathrm{Cr}>\mathrm{Cu}>\mathrm{Cd}>\mathrm{Pb}$.

\subsection{Chemical properties in soil}

The values of some selected chemical properties such as $\mathrm{pH}$, organic matter and electric conductivity in soil at the fecal sludge dumpsite in Ubakala, Nigeria is presented in Table 3. The results indicate that the highest and lowest values of soil $\mathrm{pH}$, electric conductivity and organic matter were observed at the fecal sludge dumpsite and control site, respectively. The high $\mathrm{pH}$ values in soil from the fecal sludge dumpsite may be attributed to the buffering effect of fecal matter as well as soil organic matter against $\mathrm{pH}$ change, in addition to release of high basic cations during decomposition of organic material. High basic cations are released during organic matter decomposition and this increases soil pH (Oyedele et al., 2008; Awotoye et al., 2011; Ogbonna et al., 2018b). The pH of soils from the fecal sludge dumpsite increased from $4.80 \pm 0.10$ to $6.60 \pm 0.03$ which is higher than $4.80 \pm 0.10$ recorded in soils from the control site. Thus, the soils from the fecal sludge dumpsite were less acidic unlike the soils from the control site. Soil $\mathrm{pH}$ is influenced by the use of chemicals such as fertilizers, sludge and liquid manures, and pesticides (Smith and Doran, 1996). Olness and Archer (2005) observed an increase in soil $\mathrm{pH}$ from 4.9 to 6.3 following the application of animal waste compost. The lower acidic nature of soils from the fecal sludge dumpsite can be attributed to the organic nature of the fecal sludge. Study in the composition of feces reported that majority $(84 \%)$ of the solid matter in feces is organic in nature (Lopez Zavala, 2002). The low acidic nature of soils at the fecal sludge dumpsite will facilitate the decomposition of fecal sludge by soil microorganisms' vis-à-vis the release of macronutrients and potentially toxic element in the fecal sludge dumpsite. In contrast, the strong acidic nature of soils at the control site might have hindered the effectiveness of microorganisms to decomposing organic materials since $\mathrm{pH}$ influence the inactivation of pathogen in fecal sludge (Appiah-Effah et al., 2014).

Table 3: Some chemical properties in soil

\begin{tabular}{|c|c|c|c|}
\hline Distance $(\mathrm{m})$ & $\mathrm{pH}$ & Organic Matter (\%) & $\mathrm{EC}\left(\mu \mathrm{Scm}-{ }^{1}\right)$ \\
\hline 1 & $6.60^{\mathrm{a}} \pm 0.03$ & $24.11^{\mathrm{a}} \pm 0.01$ & $33.27^{\mathrm{a}} \pm 0.83$ \\
\hline 5 & $5.75^{\mathrm{b}} \pm 0.05$ & $13.95^{\mathrm{b}} \pm 0.05$ & $20.03^{\mathrm{b}} \pm 1.05$ \\
\hline 15 & $5.12^{\mathrm{c}} \pm 0.10$ & $7.75^{\mathrm{c}} \pm 1.49$ & $15.93^{\mathrm{c}} \pm 1.17$ \\
\hline 30 & $4.80^{\mathrm{d}} \pm 0.10$ & $2.22^{\mathrm{d}} \pm 0.02$ & $9.79^{\mathrm{d}} \pm 0.58$ \\
\hline Control & $4.80^{\mathrm{d}} \pm 0.10$ & $2.14^{\mathrm{d}} \pm 0.03$ & $8.40^{\mathrm{d}} \pm 1.11$ \\
\hline
\end{tabular}

The highest level of organic matter in this study was observed to apex within $1 \mathrm{~m}(24.11 \pm 0.01)$ followed by its (organic matter) values at the distance of $5 \mathrm{~m}(13.95 \pm 0.05), 15 \mathrm{~m}(7.75 \pm 1.49)$ and 30 $\mathrm{m}(2.22 \pm 0.02)$ while the control site $(2.14 \pm 0.03)$ had the lowest level of organic matter. The level of organic matter in soil indicates that the values of organic matter in soil samples were decreasing with increasing distance from the fecal sludge dumpsite. The magnitude of decline in organic matter content with distance in this study varied amongst sampling distance but the rate of decline were higher at $30 \mathrm{~m}$, followed by $15 \mathrm{~m}$ and lastly $5 \mathrm{~m}$. The high value of organic matter at $1 \mathrm{~m}$ may be 
linked with its proximity to the fecal sludge dumpsite while the low organic matter content in soil at the control site may be attributed to low quantity of organic materials unlike the fecal sludge dumpsite area that provided sustained supply of organic matter to the soils at various distance. The level of organic matter at $1 \mathrm{~m}(24.11 \pm 0.01)$ was $1.73,3.11,10.86$ and 11.27 folds higher than its value at $5 \mathrm{~m}$, $15 \mathrm{~m}, 30 \mathrm{~m}$ and control, respectively. The organic matter content in soil from the fecal sludge dumpsite at Ubakala, Nigeria increased from $2.22 \pm 0.02$ to $24.11 \pm 0.01$, which is lower than $62.49 \pm 1.63$ to $70.36 \pm 0.88 \%$ in sewage sludge in Greece (Angelidis and Aloupi, 1999) but higher than 1.5 to 1.9 (Bozym, 2019) (Table 4), $5.12 \pm 0.02$ to $6.59 \pm 0.07 \%$ in waste dump soil (Obasi et al., 2013), 3.81 to $7.94 \%$ in municipal landfilled soil (Fonge et al., 2017) and $1.74 \pm 0.04$ to $3.88 \pm 0.08 \%$ in soil amended with sewage sludge (Elloumi et al., 2016). Soil organic matter content is an important soil quality indicator (Larson and Pierce, 1991) since it influences soil biological, physical and chemical characteristics. It (soil organic matter) is a sink and source for plant nutrients and very crucial in sustaining soil fertility, reducing erosion, influencing aggregation, and improving water infiltration and retention (Sikora and Stott, 1996; Doran et al., 1996), buffering capacity and microbial activity/diversity (Arshad and Coen, 1992).

Table 4: Comparison of concentration of some chemical properties and PTE in soils with related studies and EU standard

\begin{tabular}{|c|c|c|c|}
\hline Parameters & This study & Related studies & $\begin{array}{c}\text { EU } \\
\text { Standards }\end{array}$ \\
\hline $\mathrm{pH}$ & $4.80-6.60$ & $\begin{array}{l}\text { 7.09-7.60 Amos-Tautua et al. (2014), 8.0-8.3 Bozym (2019), } \\
\text { 7.56-8.65 Anhwange and Kaana (2013) }\end{array}$ & NA \\
\hline Organic matter & $2.22-24.11$ & 1.03-4.71 Amos-Tautua et al. (2014), 1.5-1.9 Bozym (2019. & NA \\
\hline Electrical conductivity & $9.79-33.27$ & & NA \\
\hline $\mathrm{Cr}$ & $2.40-21.03$ & $\begin{array}{l}\text { 11.40-18.34 Ajah et al. (2015), 12.0-355 Spanos et al. (2016), 39.67- } \\
48.08 \text { Vongdala et al. (2019), 53.5-134.5 Shamuyarira \& Gumbo } \\
\text { (2014), 0.10-536.5 Esakku et al. (2005), 29.21-32.41 Ayari et al. } \\
\text { (2010) }\end{array}$ & 150 \\
\hline $\mathrm{Cu}$ & $6.27-31.39$ & $\begin{array}{l}\text { 51.0-198.0, Spanos et al. (2016), 54.06-66.82 Vongdala et al. (2019), } \\
\text { 25.17-87.77 Ajahet al. (2015), 263.7-626 Shamuyarira (2013), Ideriah } \\
\text { et al. (2010), 2.18-1005 Esakkuet al. (2005), 45.0-48.23 Ayari et al. } \\
\text { (2010) }\end{array}$ & 140 \\
\hline $\mathrm{Pb}$ & $0.09-0.35$ & $\begin{array}{l}\text { 35.6-172.9 Shamuyarira (2013), 9.10-271.9 Esakku et al. (2005), } \\
\text { 52.45-56.12 Ayari et al. (2010), 125.72-138.48 Ajah et al. (2015), } \\
\text { 67.99-80.17 Vongdala et al. (2019), 12.0-102 Spanos et al. (2016) }\end{array}$ & 300 \\
\hline $\mathrm{Zn}$ & $\begin{array}{l}13.40- \\
100.80\end{array}$ & $\begin{array}{l}\text { 52.48-77.46 Vongdala et al. (2019), 86.95-98.25 Ayari et al. (2010), } \\
\text { 856.0-1880 Spanos et al. (2016), 43.37-76.37 Ajah et al. (2015), 5.52- } \\
\text { 777.9 Esakku et al. (2005), 951.0-1732 Shamuyarira (2013) }\end{array}$ & \\
\hline $\mathrm{Mn}$ & $36-188.57$ & $\begin{array}{l}\text { 263-1348 Shamuyarira (2013), 6.44-12.28 Ajah et al. (2015), 8.36- } \\
\text { 383.1 Esakku et al. (2005) }\end{array}$ & \\
\hline $\mathrm{Cd}$ & $0.07-0.92$ & $\begin{array}{l}\text { 0.8-7.3 Spanos et al. (2016), 0.82-3.11 Shamuyarira (2013), 3.73-3.76 } \\
\text { Vongdala et al. (2019), BDL-3.80 Esakku et al. (2005), 0.88-1.10 } \\
\text { Ayari et al. (2010) }\end{array}$ & 3 \\
\hline
\end{tabular}

The highest value of electrical conductivity was obtained at the distance of $1 \mathrm{~m}(33.27 \pm 0.83 \mathrm{mS} / \mathrm{cm})$ and the value is significantly $(\mathrm{P}<0.05)$ higher than values observed at $5 \mathrm{~m}(20.03 \pm 1.05 \mathrm{mS} / \mathrm{cm}), 15 \mathrm{~m}$ $(15.93 \pm 1.17 \mathrm{mS} / \mathrm{cm}), 30 \mathrm{~m}(9.79 \pm 0.58 \mathrm{mS} / \mathrm{cm})$ and control $(8.40 \pm 1.11 \mathrm{mS} / \mathrm{cm})$. The values of electrical conductivity in soil were decreasing with increasing distance from the fecal sludge dumpsite. The high values of EC in soil at the fecal sludge dumpsite may be attributed to presence of soluble salt in the fecal sludge. For instance, winery sludge (Saviozziet al., 1994) and brewery sludge (Alayu and Leta, 2020) were found to increase soil salinity, which exerts severe stress on non-salttolerant plants and inhibits the plant growth (Mtshaliet al. 2014). However, the value of soil salinity in this study was not at a level that could restrict plant growth rate and yield of crops because the EC value meets the tolerable salinity limit of most plants that ranges from 3 to $4 \mathrm{mS} / \mathrm{cm}$ (Abdullah et al. 2016. The level of EC at $1 \mathrm{~m}(33.27 \pm 0.83 \mathrm{mS} / \mathrm{cm})$ is $1.66,2.09,3.40$ and 3.96 fold higher than its values at $5 \mathrm{~m}, 15 \mathrm{~m}, 30 \mathrm{~m}$ and control, respectively. The values of EC in soil from the fecal sludge (FS) dumpsite in Ubakala, Nigeria increased from $9.79 \pm 0.58$ to $33.27 \pm 0.83 \mathrm{mS} / \mathrm{cm}$, which is higher than $1.53 \pm 0.01$ to $2.46 \pm 0.02 \mathrm{mS} / \mathrm{cm}$ in waste dump soil (Obasi et al., 2013), 0.03 to $0.04 \mathrm{mS} / \mathrm{cm}$ in municipal landfilled soil (Fonge et al., 2017) and $0.58 \pm 0.07$ to $0.80 \pm 0.08 \mathrm{dS} / \mathrm{m}$ in soil amended with sewage sludge (Elloumi et al., 2016) (Table 4). Electrical conductivity (EC) is a measure of soil 
salinity (Rhoades, 1996) and it significantly impacts microbial respiration, decomposition and other processes involved in nitrogen cycling (Smith and Doran, 1996).

\subsection{Horizontal distribution of potentially toxic element in soil}

The distribution of potentially toxic element in soil samples collected at various distance from the fecal sludge dumpsite and control site is summarized in Table 5. The results show that significant differences exist among the PTE at the various distance from the fecal sludge dumpsite. The results also indicate that highest and lowest concentrations of the PTE were observed at the fecal sludge dumpsite and control area, respectively. The high PTE in soils from the study site may be attributed to the fecal sludge dumpsite since the PTE were present in the samples of dried fecal matter analyzed in this study (Table 1) as well as the high content of organic matter in soil (Table 3). Organic matter in soils immobilizes heavy metals at strongly acidic conditions and mobilizes metals at weakly acidic to alkaline reactions by forming insoluble or soluble organic metal complexes, respectively (Brümmer and Herms, 1982). More so, the $\mathrm{pH}$ values in soils $(4.80 \pm 0.10$ to $6.60 \pm 0.03)$ of the fecal sludge dumpsite is also implicated for the high PTE values. At low pH some metallic elements are overly abundant and highly mobile (Brady and Weil, 2000). Notwithstanding this, studies have shown that sites adjoined to source of pollution are subjected to high concentration of PTE such as heavy metals unlike the control site (Ogbonna et al., 2013, 2018c, 2020b) The concentration of six (6) PTE tested in the soil was observed to climax within $1 \mathrm{~m}$ followed by their (PTE) values at the distance of $5 \mathrm{~m}, 15$ $\mathrm{m}, 30 \mathrm{~m}$ while the control site had the lowest concentration of the PTE. The pattern of migration of the PTE in soil suggests that the concentration of PTE in soil sample were decreasing with increasing distance from the fecal sludge dumpsite. Similar pattern in distribution of PTE ( $\mathrm{Pb}, \mathrm{Cd}, \mathrm{As}, \mathrm{Ni}, \mathrm{Fe}$ and $\mathrm{Zn}$ ) with highest concentration at $1 \mathrm{~m}$ and decreased with distance has been reported in a related study at Ngwogwo in Ebonyi State, Nigeria (Ogbonna et al., 2020b).

The highest concentrations of $\mathrm{Zn}(100.80 \pm 1.40 \mathrm{mg} / \mathrm{kg}), \mathrm{Cd}(0.92 \pm 0.02 \mathrm{mg} / \mathrm{kg}), \mathrm{Cu}(31.39 \pm 1.04$ $\mathrm{mg} / \mathrm{kg}), \mathrm{Mn}(188.57 \pm 2.25 \mathrm{mg} / \mathrm{kg}), \mathrm{Cr}(21.03 \pm 1.43 \mathrm{mg} / \mathrm{kg})$ and $\mathrm{Pb}(0.35 \pm 0.03 \mathrm{mg} / \mathrm{kg})$ were recorded in soil at a distance of $1 \mathrm{~m}$ from the fecal sludge dumpsite. The values of $\mathrm{Zn}, \mathrm{Cd}, \mathrm{Cu}, \mathrm{Mn}, \mathrm{Cr}$ and $\mathrm{Pb}$ at $1 \mathrm{~m}$ are significantly $(\mathrm{P}<0.05)$ higher than their values at $5 \mathrm{~m}(87.30 \pm 2.75,0.62 \pm 0.02,19.13 \pm 0.15$, $119.90 \pm 0.95,10.07 \pm 1.10$ and $0.28 \pm 0.01 \mathrm{mg} / \mathrm{kg})$ and $15 \mathrm{~m}(37.33 \pm 0.99,0.11 \pm 0.01,13.63 \pm 0.47$, $94.07 \pm 1.01,6.00 \pm 0.20$ and $0.16 \pm 0.00 \mathrm{mg} / \mathrm{kg}$ ). Similarly, the values of PTE at $1 \mathrm{~m}$ is significantly $(\mathrm{P}<0.05)$ higher than their values at $30 \mathrm{~m}(13.40 \pm 1.20,0.07 \pm 0.01,6.27 \pm 0.31,36.00 \pm 1.56,2.40 \pm 0.40$ and $0.09 \pm 0.02 \mathrm{mg} / \mathrm{kg})$ as well as the control $(2.10 \pm 0.02,0.00 \pm 0.00,0.45 \pm 0.03,9.36 \pm 1.50,0.01 \pm 0.00$ and $0.00 \pm 0.00 \mathrm{mg} / \mathrm{kg}$ ) for $\mathrm{Zn}, \mathrm{Cd}, \mathrm{Cu}, \mathrm{Mn}, \mathrm{Cr}$ and $\mathrm{Pb}$, respectively. The PTE in the large volume of fecal sludge dumpsite may have provided a source for continued leaching and migration via runoff and have culminated to various level of contamination of $\mathrm{Zn}, \mathrm{Cd}, \mathrm{Cu}, \mathrm{Mn}, \mathrm{Cr}$ and $\mathrm{Pb}$ at the various distance of 1, 5, 15 and $30 \mathrm{~m}$. Potentially toxic element like heavy metals are part of the composition of fecal sludge (Hashem, 2000).

Table 5: Heavy metal concentration in soils at various distances from fecal sludge dumpsite

\begin{tabular}{lcccccc}
\hline Distance $(\mathrm{m})$ & $\mathrm{Zn}$ & $\mathrm{Cd}$ & $\mathrm{Cu}$ & $\mathrm{Mn}$ & $\mathrm{Cr}$ & $\mathrm{Pb}$ \\
\hline 1 & $100.80^{\mathrm{a}} \pm 1.40$ & $0.92^{\mathrm{a}} \pm 0.02$ & $31.39^{\mathrm{a}} \pm 1.04$ & $188.57^{\mathrm{a}} \pm 2.25$ & $21.03^{\mathrm{a}} \pm 1.43$ & $0.35^{\mathrm{a}} \pm 0.03$ \\
5 & $87.30^{\mathrm{b}} \pm 2.75$ & $0.62^{\mathrm{b}} \pm 0.02$ & $19.13^{\mathrm{b}} \pm 0.15$ & $119.90^{\mathrm{b}} \pm 0.95$ & $10.07^{\mathrm{b}} \pm 1.10$ & $0.28^{\mathrm{b}} \pm 0.01$ \\
15 & $37.33^{\mathrm{c}} \pm 0.99$ & $0.11^{\mathrm{c}} \pm 0.01$ & $13.63^{\mathrm{c}} \pm 0.47$ & $94.07^{\mathrm{c}} \pm 1.01$ & $6.00^{\mathrm{c}} \pm 0.20$ & $0.16^{\mathrm{c}} \pm 0.00$ \\
30 & $13.40^{\mathrm{d}} \pm 1.20$ & $0.07^{\mathrm{d}} \pm 0.01$ & $6.27^{\mathrm{d}} \pm 0.31$ & $36.00^{\mathrm{d}} \pm 1.56$ & $2.40^{\mathrm{d}} \pm 0.40$ & $0.09^{\mathrm{d}} \pm 0.02$ \\
Control & $2.10^{\mathrm{e}} \pm 0.02$ & $0.00^{\mathrm{e}} \pm 0.00$ & $0.45^{\mathrm{e}} \pm 0.03$ & $9.36^{\mathrm{e}} \pm 1.50$ & $0.01^{\mathrm{e}} \pm 0.00$ & $0.00^{\mathrm{e}} \pm 0.00$ \\
\hline \multicolumn{5}{c}{ Values are mean \pm standard deviation of 3 replicates } \\
& \multicolumn{5}{c}{ Means in a column with different superscripts are significantly different $(P<0.05)$}
\end{tabular}

The concentration of $\mathrm{Zn}$ in soil at the fecal sludge dumpsite was $13.40 \pm 1.20$ to $100.80 \pm 1.40 \mathrm{mg} / \mathrm{kg}$, which is below the Environmental Quality Standard of $421 \mathrm{mg} / \mathrm{kg}(\mathrm{Zn})$ set by National Environmental Standards and Regulations Enforcement Agency, NESREA (NESREA, 2011) of Nigeria, the accepted limit (i.e. target value) of $140 \mathrm{mg} / \mathrm{kg}(\mathrm{Zn})$ as described by Dutch criteria for soil (Ogbonna et al., $2020 \mathrm{~b}$ ) but higher than $60 \mathrm{mg} / \mathrm{kg}(\mathrm{Zn})$ established by Codex Alimentarius Commission (FAO/WHO, 2001) (Table 6). The concentration of $\mathrm{Zn}(100.80 \pm 1.40 \mathrm{mg} / \mathrm{kg})$ at $1 \mathrm{~m}$ is $1.15,2.70,7.52$ and 48 times higher than its values at $5 \mathrm{~m}, 15 \mathrm{~m}, 30 \mathrm{~m}$ from the fecal sludge dumpsite and control, respectively. The concentration of $\mathrm{Zn}(13.40 \pm 1.20$ to $100.80 \pm 1.40 \mathrm{mg} / \mathrm{kg})$ in soils at the various distance from the 
fecal sludge dumpsite is lower than $122.92 \pm 0.06$ to $235.75 \pm 0.04 \mathrm{mg} / \mathrm{kg}$ in soil at waste dumpsite in Uyo, Akwa Ibom State, Nigeria (Nkop et al., 2016) but higher than 43.37 to $76.37 \mathrm{mg} / \mathrm{kg}$ in soil at MSW dumpsite in Enugu State, Nigeria (Ajah et al., 2015), 13.82 to $17.26 \mathrm{mg} / \mathrm{kg}$ in soil at MSW dumpsite in Benue State, Nigeria (Anhwange and Kaana, 2013). The differences in the concentrations of PTE in soil from the fecal sludge area and municipal solid waste dumpsites may be attributed to source of wastes, composition and length of time the wastes has lasted at the dumpsites. Zinc is an essential nutrient in soil for the growth and development of plants.

The concentration of $\mathrm{Cd}$ in soil at the fecal sludge dumpsite was $0.07 \pm 0.01$ to $0.92 \pm 0.02 \mathrm{mg} / \mathrm{kg}$, which is higher than the maximum permitted level of $0.1 \mathrm{mg} / \mathrm{kg}(\mathrm{Cd})$ established by the Codex Alimentarius Commission (FAO/WHO, 2001), the accepted limit of $0.8 \mathrm{mg} / \mathrm{kg}(\mathrm{Cd})$ as described by Dutch criteria for soil (Ogbonna et al., 2020b) but lower than $50 \mathrm{mg} / \mathrm{kg}$ (Cd) set by National Environmental Standards and Regulations Enforcement Agency, NESREA (NESREA, 2011) of Nigeria. The concentration of $\mathrm{Cd}(0.92 \pm 0.02 \mathrm{mg} / \mathrm{kg})$ at $1 \mathrm{~m}$ is $1.48,8.36,13.14$ and 92 times higher than its values at $5 \mathrm{~m}, 15 \mathrm{~m}, 30 \mathrm{~m}$ from the fecal sludge dumpsite and control, respectively. The concentration of $\mathrm{Cd}(0.07 \pm 0.01$ to $0.92 \pm 0.02 \mathrm{mg} / \mathrm{kg})$ in soils at the various distances from the fecal sludge dumpsite is lower than 219 to $330 \mathrm{mg} / \mathrm{kg}$ in soil at waste dumpsite (Awokunmi et al., 2010).

Table 6: Comparison of concentration of heavy metals in soils with international and national standards (*ECDGE, 2010); Ogbonna et al. (2020a)

\begin{tabular}{|c|c|c|c|c|c|c|c|c|c|c|c|c|}
\hline 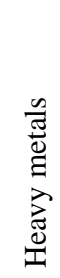 & 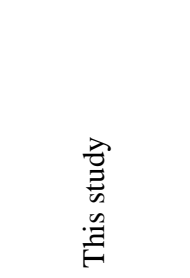 & 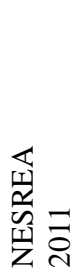 & 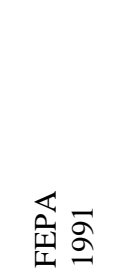 & 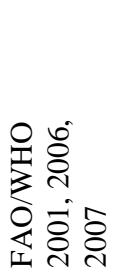 & 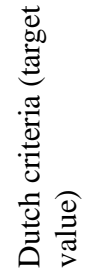 & 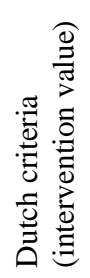 & $\begin{array}{c}\frac{\tilde{D}}{0} \\
\frac{D}{\delta} \\
* \\
*\end{array}$ & 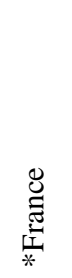 & 当 & 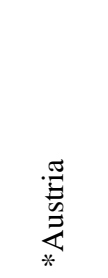 & 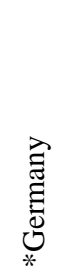 & 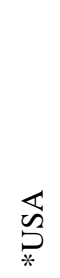 \\
\hline $\mathrm{Cr}$ & $2.40-21.03$ & 100 & NA & 100 & 100 & 380 & 60 & 150 & 400 & 100 & 60 & NA \\
\hline $\mathrm{Cu}$ & $6.27-31.39$ & 100 & $70-80$ & 100 & 36 & 190 & 40 & 100 & 135 & $60-100$ & 40 & 75 \\
\hline $\mathrm{Pb}$ & $0.09-0.35$ & 164 & 1.6 & 50 & 85 & 530 & 40 & 100 & 300 & 100 & 70 & 15 \\
\hline $\mathrm{Zn}$ & $13.40-100.80$ & 421 & $300-400$ & 60 & 140 & 720 & NA & NA & NA & NA & NA & 140 \\
\hline $\mathrm{Mn}$ & $36-188.57$ & NA & NA & NA & NA & NA & NA & NA & NA & NA & NA & NA \\
\hline $\mathrm{Cd}$ & $0.07-0.92$ & 3 & 0.01 & 0.1 & 0.8 & 12 & 0.4 & 2 & 3 & $1-2$ & 1 & 1.9 \\
\hline
\end{tabular}

The concentrations of $\mathrm{Cu}$ and $\mathrm{Mn}$ in soil at the fecal sludge dumpsite in Ubakala, Nigeria were $6.27 \pm 0.31$ to $31.39 \pm 1.04$ and $36.00 \pm 1.56$ to $188.57 \pm 2.25 \mathrm{mg} / \mathrm{kg}$, respectively for $\mathrm{Cu}$ and $\mathrm{Mn}$. The values of $\mathrm{Cu}$ in soil at the fecal sludge dumpsite at Ubakala, Nigeria was $6.27 \pm 0.31$ to $31.39 \pm 1.04$ $\mathrm{mg} / \mathrm{kg}$, which is lower than the maximum permitted level of $100 \mathrm{mg} / \mathrm{kg}(\mathrm{Cu})$ established by Codex Alimentarius Commission (FAO/WHO, 2001), the accepted limit of $36 \mathrm{mg} / \mathrm{kg}(\mathrm{Cu})$ as described by Dutch criteria for soil (Ogbonna et al., 2018a), $100 \mathrm{mg} / \mathrm{kg}(\mathrm{Cu})$ set by National Environmental Standards and Regulations Enforcement Agency, NESREA (NESREA, 2011) and 70-80 mg/kg (Cu) set by Federal Ministry of Environment (FMEnv, 2002) of Nigeria. The concentration of $\mathrm{Cu}$ $(31.39 \pm 1.04 \mathrm{mg} / \mathrm{kg})$ at $1 \mathrm{~m}$ is $1.64,2.30,5.01$ and 69.76 times higher than its values at $5 \mathrm{~m}, 15 \mathrm{~m}, 30$ $\mathrm{m}$ from the fecal sludge dumpsite and control, respectively. The concentration of $\mathrm{Cu}(6.27 \pm 0.31$ to $31.39 \pm 1.04 \mathrm{mg} / \mathrm{kg}$ ) in soils at the various distance from the fecal sludge dumpsite is lower than $2.18 \pm 0.1$ to $1005.2 \pm 6.0 \mathrm{mg} / \mathrm{kg}$ in soil (Esakku et al., 2005) but higher than 6.68 to $11.4 \mathrm{mg} / \mathrm{kg}$ in soil (Anhwange and Kaana, 2013).

The concentration of $\mathrm{Mn}(188.57 \pm 2.25 \mathrm{mg} / \mathrm{kg})$ at $1 \mathrm{~m}$ is $1.57,2.00,5.24$ and 20.15 times higher than its values at $5 \mathrm{~m}, 15 \mathrm{~m}, 30 \mathrm{~m}$ from the fecal sludge dumpsite and control, respectively. The concentration of $\mathrm{Mn}(36.00 \pm 1.56$ to $188.57 \pm 2.25 \mathrm{mg} / \mathrm{kg})$ in soils at the various distance from the fecal sludge dumpsite is lower than $2000 \mathrm{mg} / \mathrm{kg}$ (Mn) in soil (FAO/WHO, 1984) but higher than 6.44 to $12.28 \mathrm{mg} / \mathrm{kg}$ in soil at MSW dumpsite in Enugu State, Nigeria (Ajah et al., 2015).

The concentrations of $\mathrm{Cr}$ and $\mathrm{Pb}$ in soil at the fecal sludge dumpsite were $2.40 \pm 0.40$ to $21.03 \pm 1.43$ and $0.09 \pm 0.02$ to $0.35 \pm 0.03 \mathrm{mg} / \mathrm{kg}$, respectively. The values of $\mathrm{Cr}(2.40 \pm 0.40$ to $21.03 \pm 1.43 \mathrm{mg} / \mathrm{kg})$ is well below the accepted limit of $100 \mathrm{mg} / \mathrm{kg}(\mathrm{Cr})$ as described by Dutch criteria for soil (Ogbonna et al., 2020a), the $100 \mathrm{mg} / \mathrm{kg}$ (Cr) established by Codex Alimentarius Commission (FAO/WHO, 2001), 
the $100 \mathrm{mg} / \mathrm{kg}(\mathrm{Cr})$ set by National Environmental Standards and Regulations Enforcement Agency, NESREA of Nigeria (NESREA, 2011), $50 \mathrm{mg} / \mathrm{kg}$ (Cr) set by Ministry of Agriculture, Fisheries and Food, MAFF (MAFF, 1992) and $50 \mathrm{mg} / \mathrm{kg}$ (Cr) set by the European Commission, EC (EC, 1986). The concentration of $\mathrm{Cr}(21.03 \pm 1.43 \mathrm{mg} / \mathrm{kg})$ at $1 \mathrm{~m}$ is $2.09,3.51,8.76$ and 2,103 times higher than its values at $5 \mathrm{~m}, 15 \mathrm{~m}, 30 \mathrm{~m}$ from the fecal sludge dumpsite and control, respectively. The concentration of $\mathrm{Cr}(2.40 \pm 0.40$ to $21.03 \pm 1.43 \mathrm{mg} / \mathrm{kg})$ in soils at the various distances from the fecal sludge dumpsite is lower than $239.00 \pm 120$ to $677.00 \pm 232 \mathrm{mg} / \mathrm{kg}$ in soil of landfilled foundry site in Poland (Bozym, 2019).

The concentration of $\mathrm{Pb}$ in soil at the fecal sludge dumpsite was $0.09 \pm 0.02$ to $0.35 \pm 0.03 \mathrm{mg} / \mathrm{kg}$, which is well below $164 \mathrm{mg} / \mathrm{kg}(\mathrm{Pb})$ set by National Environmental Standards and Regulations Enforcement Agency, NESREA (NESREA, 2011) of Nigeria, the accepted limit of $85 \mathrm{mg} / \mathrm{kg}(\mathrm{Pb})$ described by Dutch criteria for soil (Ogbonna et al., 2020a) and the maximum permitted level of 50 $\mathrm{mg} / \mathrm{kg}(\mathrm{Pb})$ established by Codex Alimentarius Commission (FAO/WHO, 2001) (Table 6). The concentration of $\mathrm{Pb}(0.35 \pm 0.03 \mathrm{mg} / \mathrm{kg})$ at $1 \mathrm{~m}$ is $1.25,2.19,3.89$ and 35 times higher than its values at $5 \mathrm{~m}, 15 \mathrm{~m}, 30 \mathrm{~m}$ from the fecal sludge dumpsite and control, respectively. The concentration of $\mathrm{Pb}$ $(0.09 \pm 0.02$ to $0.35 \pm 0.03 \mathrm{mg} / \mathrm{kg})$ in soils at the various distances from the fecal sludge dumpsite is lower than $9.10 \pm 0.1$ to $271.9 \pm 22 \mathrm{mg} / \mathrm{kg}$ in soil (Esakku et al., 2005) and 125.72 to $138.48 \mathrm{mg} / \mathrm{kg}$ in soil (Ajah et al., 2015). Generally, the concentration of the potentially toxic element in soil followed a decreasing order: $\mathrm{Mn}>\mathrm{Zn}>\mathrm{Cu}>\mathrm{Cr}>\mathrm{Cd}>\mathrm{Pb}$. The purpose of ranking the PTEs is to show their level of distribution in soil in order of concentrations.

\subsection{Potentially toxic element in food crops}

Table 7 shows the concentrations of $\mathrm{Cd}, \mathrm{Cu}, \mathrm{Pb}, \mathrm{Mn}, \mathrm{Cr}$ and $\mathrm{Zn}$ in leaves of Carica papaya $\mathrm{L}$, Telfairia occidentalis Hook $\mathrm{f}$. and Manihot esculenta Crantz sampled at the fecal sludge dumpsite area and control site of Ubakala, Nigeria. The results showed that the leaf concentrations of potentially toxic element in the contaminated site were significantly higher than that of the control site in all plant species. The result also indicates significant differences among the plant species sampled from the study site (i.e. fecal sludge dumpsite area). The disparity in concentrations of potentially toxic element in plant species tested in this study may be attributed to their dissimilarity in inherent ability to uptake potentially toxic element from soil (Ogbonna et al., 2018a). From the results, the highest concentrations of $\mathrm{Zn}(56.02 \pm 5.02 \mathrm{mg} / \mathrm{kg}), \mathrm{Cd}(0.085 \pm 0.01 \mathrm{mg} / \mathrm{kg}), \mathrm{Cr}(9.60 \pm 1.13 \mathrm{mg} / \mathrm{kg})$ and $\mathrm{Pb}(0.008 \pm 0.00 \mathrm{mg} / \mathrm{kg})$ were assimilated in the Carica papaya leaves and the values are significantly $(\mathrm{P}<0.05)$ different from their $(\mathrm{Zn}, \mathrm{Cd}, \mathrm{Cr}$ and $\mathrm{Pb})$ values in Telfairia occidentalis and Manihot esculenta as well as some values of Carica papaya at various distance from the fecal sludge dumpsite (Table 7). The high concentrations of $\mathrm{Zn}, \mathrm{Cd}, \mathrm{Cr}$ and $\mathrm{Pb}$ in Carica papaya leaves may be attributed to its network of fibrous root that offered large surface area at the surface soil $(0-15 \mathrm{~cm})$ and beyond the surface soil $(16-50 \mathrm{~cm})$ as well as horizontal spread of its roots in soil. The papaya root is predominately a non-axial, fibrous system, composed of one or two $0.5-1.0 \mathrm{~m}$ long tap roots, and secondary roots that branch profusely (Marler and Discekici, 1997; Carneiro and Cruz, 2009).

The concentration of $\mathrm{Zn}$ increased from $1.24 \pm 0.06$ to $56.02 \pm 5.02 \mathrm{mg} / \mathrm{kg}$, which is higher than 22.09 to $45.71 \mathrm{mg} / \mathrm{kg}$ in tomato growing on soil amended with applied sewage sludge (Elloumi et al., 2016), $5.96 \pm 0.02$ to $28.85 \pm 0.04 \mathrm{mg} / \mathrm{kg}$ in Amaranthus hibridus, Talinum triangulare, Carica papaya, Ipomea batatas and Luffa aegyptiaca at waste dump site (Obasi et al., 2013), 0.02 to $0.40 \mathrm{mg} / \mathrm{kg}$ in Zea mays, Hibiscus sabdarifa, Abelmuschus esculentus, Amaranthus dubius and Arachis hypogea at municipal waste dumpsite in Nasarawa State, Nigeria (Opaluwa et al., 2012). The concentration of Zn $(1.24 \pm 0.06$ to $56.02 \pm 5.02 \mathrm{mg} / \mathrm{kg})$ in this study is relatively higher than the permissible limit of 50 $\mathrm{mg} / \mathrm{kg}(\mathrm{Zn})$ established by the Codex Alimentarius Commission (FAO/WHO, 2006) (Table 8). Zinc is an essential element for healthy growth and development of plants, animal and man but will be harmful to flora and fauna when thethreshold limit is exceeded. High level of $\mathrm{Zn}$ is known to inhibit copper absorption, resulting to $\mathrm{Cu}$ deficiency symptoms (Tothert et al., 2016). Its ( $\mathrm{Zn}$ ) deficiency in flora and fauna may result to stunted growth and impair cell division. 
Table 7: Heavy metal concentration in plants at various distances from the fecal waste dumpsite

\begin{tabular}{|c|c|c|c|c|c|c|c|}
\hline $\begin{array}{l}\text { Distance } \\
(\mathrm{m})\end{array}$ & Plant species & $\mathrm{Zn}$ & $\mathrm{Cd}$ & $\mathrm{Cu}$ & $\mathrm{Cr}$ & $\mathrm{Pb}$ & $\mathrm{Mn}$ \\
\hline \multirow[t]{3}{*}{1} & $\begin{array}{l}\text { Telfairia } \\
\text { occidentalis }\end{array}$ & $26.14^{\mathrm{c}} \pm 2.10$ & $0.007^{\mathrm{c}} \pm 0.00$ & $10.80^{\mathrm{a}} \pm 2.01$ & $4.01^{\mathrm{b}} \pm 0.02$ & $0.001^{\mathrm{b}} \pm 0.00$ & $17.21^{\mathrm{a}} \pm 2.01$ \\
\hline & Carica & $56.02^{\mathrm{a}} \pm 5.02$ & $0.085^{\mathrm{a}} \pm 0.01$ & $5.10^{\mathrm{b}} \pm 0.03$ & $9.60^{\mathrm{a}} \pm 1.13$ & $0.008^{\mathrm{a}} \pm 0.00$ & $8.60^{\mathrm{b}} \pm 1.03$ \\
\hline & $\begin{array}{l}\text { papaya } \\
\text { Manihot } \\
\text { esculenta }\end{array}$ & $37.60^{\mathrm{b}} \pm 3.28$ & $0.011^{\mathrm{c}} \pm 0.01$ & $2.94^{\mathrm{c}} \pm 0.06$ & $2.06^{\mathrm{b}} \pm 0.04$ & $0.001^{\mathrm{b}} \pm 0.00$ & $4.91^{\mathrm{c}} \pm 0.10$ \\
\hline \multirow[t]{3}{*}{5} & $\begin{array}{l}\text { Telfairia } \\
\text { occidentalis }\end{array}$ & $14.20^{\mathrm{d}} \pm 1.20$ & $0.005^{\mathrm{d}} \pm 0.00$ & $1.84^{\mathrm{cd}} \pm 0.01$ & $0.60^{c} \pm 0.01$ & $0.0001^{\mathrm{c}} \pm 0.00$ & $3.20^{\mathrm{c}} \pm 0.13$ \\
\hline & Carica & $24.11^{\mathrm{c}} \pm 2.82$ & $0.010^{\mathrm{c}} \pm 0.01$ & $1.04^{\mathrm{d}} \pm 0.02$ & $0.82^{\mathrm{c}} \pm 0.02$ & $0.0003^{c} \pm 0.01$ & $1.60^{\mathrm{d}} \pm 0.01$ \\
\hline & $\begin{array}{l}\text { Manihot } \\
\text { esculenta }\end{array}$ & $16.23^{\mathrm{d}} \pm 2.04$ & $0.009^{c} \pm 0.02$ & $0.88^{\mathrm{d}} \pm 0.04$ & $0.63^{\mathrm{c}} \pm 0.01$ & $0.0002^{c} \pm 0.00$ & $1.00^{\mathrm{d}} \pm 0.03$ \\
\hline \multirow[t]{3}{*}{15} & $\begin{array}{l}\text { Telfairia } \\
\text { occidentalis }\end{array}$ & $5.12^{\mathrm{e}} \pm 0.12$ & $0.001^{\mathrm{d}} \pm 0.00$ & $0.28^{\mathrm{e}} \pm 0.01$ & $0.04^{\mathrm{d}} \pm 0.00$ & $0.00001^{\mathrm{d}} \pm 0.00$ & $0.72^{\mathrm{e}} \pm 0.01$ \\
\hline & Carica & $7.00^{\mathrm{e}} \pm 0.14$ & $0.008^{c} \pm 0.00$ & $0.64^{\mathrm{de}} \pm 0.02$ & $0.07^{\mathrm{d}} \pm 0.00$ & $0.00002^{\mathrm{d}} \pm 0.01$ & $0.31^{\mathrm{e}} \pm 0.02$ \\
\hline & $\begin{array}{l}\text { papaya } \\
\text { Manihot } \\
\text { esculenta }\end{array}$ & $6.01^{\mathrm{e}} \pm 0.04$ & $0.003^{\mathrm{d}} \pm 0.001$ & $1.03^{\mathrm{d}} \pm 0.03$ & $0.02^{\mathrm{d}} \pm 0.00$ & $0.00001^{\mathrm{d}} \pm 0.01$ & $0.28^{\mathrm{e}} \pm 0.00$ \\
\hline \multirow[t]{3}{*}{30} & $\begin{array}{l}\text { Telfairia } \\
\text { occidentalis }\end{array}$ & $1.24^{\mathrm{f}} \pm 0.06$ & $0.0000^{\mathrm{e}} \pm 0.000$ & $0.002^{\mathrm{f}} \pm 0.001$ & $0.000^{\mathrm{e}} \pm 0.00$ & $<0.00001^{\mathrm{e}} \pm 0.00$ & $0.20^{\mathrm{e}} \pm 0.00$ \\
\hline & $\begin{array}{l}\text { Carica } \\
\text { papaya }\end{array}$ & $2.01^{\mathrm{f}} \pm 0.00$ & $0.0000^{\mathrm{e}} \pm 0.000$ & $0.008^{\mathrm{f}} \pm 0.001$ & $0.001^{\mathrm{e}} \pm 0.00$ & $<0.00001^{\mathrm{e}} \pm 0.00$ & $0.18^{\mathrm{e}} \pm 0.01$ \\
\hline & $\begin{array}{l}\text { Manihot } \\
\text { esculenta }\end{array}$ & $1.68^{\mathrm{f}} \pm 0.03$ & $0.0000^{\mathrm{e}} \pm 0.000$ & $0.009^{\mathrm{f}} \pm 0.002$ & $0.000^{\mathrm{e}} \pm 0.00$ & $<0.00001^{\mathrm{e}} \pm 0.00$ & $0.11^{\mathrm{e}} \pm 0.00$ \\
\hline \multirow[t]{3}{*}{ Control } & $\begin{array}{l}\text { Telfairia } \\
\text { occidentalis }\end{array}$ & $0.22^{\mathrm{g}} \pm 0.00$ & BDL & $<0.0001^{\mathrm{g}} \pm 0.00$ & BDL & BDL & $0.06^{\mathrm{f}} \pm 0.00$ \\
\hline & Carica & $0.70^{\mathrm{g}} \pm 0.01$ & $\mathrm{BDL}$ & $<0.0001^{\mathrm{g}} \pm 0.00$ & $\mathrm{BDL}$ & $\mathrm{BDL}$ & $0.04^{\mathrm{f}} \pm 0.00$ \\
\hline & $\begin{array}{l}\text { Manihot } \\
\text { esculenta }\end{array}$ & $0.31^{\mathrm{g}} \pm 0.00$ & BDL & $<0.0001^{\mathrm{g}} \pm 0.00$ & BDL & BDL & $0.01^{\mathrm{f}} \pm 0.00$ \\
\hline
\end{tabular}

Values are mean \pm standard deviation of 3 replicates

${ }^{a b c}$ Means in a column with different superscripts are significantly different $(P<0.05)$

The concentration of $\mathrm{Cd}$ in the food crops increased from $0.0000 \pm 0.000$ to $0.085 \pm 0.01 \mathrm{mg} / \mathrm{kg}$, which is lower than 0.05 to $1.55 \mathrm{mg} / \mathrm{kg}$ in Xanthosomasagittifolium, Telfairia occidentalis and Amaranthus hybridus at municipal solid waste dumpsite in Awka, Nigeria (Nduka et al., 2008). The concentration of $\mathrm{Cd}(0.0000 \pm 0.000$ to $0.085 \pm 0.01 \mathrm{mg} / \mathrm{kg})$ in food crops is lower than the permissible limit of 0.2 $\mathrm{mg} / \mathrm{kg}$ (Cd) established by the Codex Alimentarius Commission (FAO/WHO, 2006) (Table 8). Cadmium is a non-essential element in plant metabolism and has no nutritional benefits in human body (Ogbonna et al., 2020b). It (Cd) can be toxic even at low concentrations (Jain et al., 2007; Ogbonna et al., 2020a) as it replaces Zn biochemically and cause kidney damage (Feng et al., 2011).

The concentration of $\mathrm{Pb}$ in this study increased from $<0.00001 \pm 0.00$ to $0.008 \pm 0.00 \mathrm{mg} / \mathrm{kg}$, which is lower than $1.95 \pm 0.04$ to $16.75 \pm 0.04 \mathrm{mg} / \mathrm{kg}$ in A. hybridus, T. triangulare, C. papaya, I. batatas and $L$. aegyptiaca (Obasi et al., 2013) and 0.10 to $1.74 \mathrm{mg} / \mathrm{kg}$ in $X$. sagittifolium, T. occidentals and $A$. hybridus (Nduka et al., 2008). The concentration of $\mathrm{Pb}(<0.00001 \pm 0.00$ to $0.008 \pm 0.00 \mathrm{mg} / \mathrm{kg})$ in food crops is lower than the permissible limit of $0.30 \mathrm{mg} / \mathrm{kg}(\mathrm{Cd})$ established by the Codex Alimentarius Commission (FAO/WHO, 2007). Lead (Pb) is a non-essential element in plant metabolism and has no nutritional benefit in human body. Lead $(\mathrm{Pb})$ exposure can impair brain and nervous system, cause chronic kidney disease even at relatively low blood Pb levels (ATSDR, 2007; IARC, 2006).

The concentration of $\mathrm{Cr}$ in plant leaves increased from $0.000 \pm 0.00$ to $9.60 \pm 1.13 \mathrm{mg} / \mathrm{kg}$, which is lower than 0.12 to $25.0 \mathrm{mg} / \mathrm{kg}$ in tomato (Elloumi et al., 2016). The concentration of $\mathrm{Cr}(0.000 \pm 0.00$ to $9.60 \pm 1.13 \mathrm{mg} / \mathrm{kg}$ ) in plant leaves is higher than the permissible limit of $2.30 \mathrm{mg} / \mathrm{kg}(\mathrm{Cr})$ established by Codex Alimentarius Commission (FAO/WHO, 2006). The fecal sludge with $4.47 \pm 0.34 \mathrm{mg} / \mathrm{kg}(\mathrm{Cr})$ and high concentration of $\mathrm{Cr}(21.03 \pm 1.43 \mathrm{mg} / \mathrm{kg})$ in soil are implicated for the high values of $\mathrm{Cr}$ above the permissible limit of FAO/WHO in plant leaves. Chromium is essential for carbohydrate metabolism in animals (Tucker et al., 2005) but its (Cr) concentration in food crops tested in this study pose serious health risk to man and animals that depend on $C$. papaya leaves for food and 
medicine in South east Nigeria. For instance, the leaves of $C$. papaya are a viable forage for West African dwarf (WAD) goats while infusion of the leaves is used therapeutically for treatment of malaria, headache and wound-healing. Besides the effects on hepatic and renal toxicity, C. papaya displays anti-malaria actions (Bhat and Surolia, 2001; Udoh et al., 2005; Imaga and Adepoju, 2010; Aravind et al., 2013), antitumor, wound-healing and free radical scavenging activity (Basalingappa $e t$ al., 2018), antimicrobial (Olagunju et al., 2009) and immunomodulatory activity on peripheral human blood mononuclear cells (Otsuki et al., 2010). Exposure to $\mathrm{Cr}$ could lead to allergic dermatitis in human, bleeding of the gastrointestinal tract, cancer of the respiratory tract and ulcers of the skin (Bhagure and Mirgane, 2010; Al Hagibi et al., 2018).

Table 8: Comparison of concentration of heavy metals in plants with international and national standards

\begin{tabular}{|c|c|c|c|c|c|c|}
\hline $\begin{array}{l}\text { Heavy } \\
\text { metals }\end{array}$ & This study & Related studies & NESREA & $\begin{array}{l}\text { FAO/WHO } \\
2001,2006, \\
2007\end{array}$ & FEPA & DPR \\
\hline $\mathrm{Zn}$ & $\begin{array}{l}1.24 \pm 0.06 \text { to } \\
56.02 \pm 5.02\end{array}$ & 0.30-212.7 Onyedikachi et al. (2018) & NA & 0.3 & NA & NA \\
\hline $\mathrm{Cd}$ & $\begin{array}{l}0.0000 \pm 0.000 \text { to } \\
0.085 \pm 0.01\end{array}$ & 55.4-136.7 Raimi et al. (2019) & NA & 1.63 & NA & NA \\
\hline $\mathrm{Cu}$ & $\begin{array}{l}0.002 \pm 0.001 \text { to } \\
10.80 \pm 2.01\end{array}$ & 40.4-720.6 Al-Farraj and Al-Wabel, 2007 & NA & 50 & NA & NA \\
\hline $\mathrm{Cr}$ & $\begin{array}{l}0.000 \pm 0.00 \text { to } \\
9.60 \pm 1.13\end{array}$ & 49-7,521 González-Chávez et al. (2015) & NA & 0.2 & NA & NA \\
\hline $\mathrm{Pb}$ & $\begin{array}{l}<0.00001 \pm 0.00 \\
\text { to } 0.008 \pm 0.00\end{array}$ & 54.1-134.3 Raimi et al. (2019) & NA & 0.2 & NA & NA \\
\hline $\mathrm{Mn}$ & $\begin{array}{l}0.11 \pm 0.00 \text { to } \\
17.21 \pm 2.01\end{array}$ & $\begin{array}{l}\text { 205-9,432 Olufemi et al. (2014) } \\
\text { 196.5-2,925 Raimi et al. (2019) } \\
\text { 31.95-2,654.11 Onyedikachi et al. (2018) }\end{array}$ & NA & 425 & NA & NA \\
\hline
\end{tabular}

The highest concentrations of $\mathrm{Cu}(10.80 \pm 2.01 \mathrm{mg} / \mathrm{kg})$ and $\mathrm{Mn}(17.21 \pm 2.01 \mathrm{mg} / \mathrm{kg})$ are recorded in Telfairia occidentalis leaves and the values are significantly $(\mathrm{P}<0.05)$ higher than their $(\mathrm{Cu}$ and $\mathrm{Mn})$ highest values in $C$. papaya and $M$. esculenta leaves. The concentration of $\mathrm{Cu}$ increased from $0.002 \pm 0.001$ to $10.80 \pm 2.01 \mathrm{mg} / \mathrm{kg}$, which is lower than 7.15 to $32.34 \mathrm{mg} / \mathrm{kg}$ in tomato (Elloumi et al., 2016) and $1.37 \pm 0.01$ to $28.90 \pm 0.01 \mathrm{mg} / \mathrm{kg}$ in A. hybridus, T. triangulare, C. papaya, I. batatas and $L$. aegyptiaca (Obasi et al., 2013). The concentration of $\mathrm{Cu}(0.002 \pm 0.001$ to $10.80 \pm 2.01 \mathrm{mg} / \mathrm{kg})$ is below the permissible limit of $73.0 \mathrm{mg} / \mathrm{kg}(\mathrm{Cu})$ set by Codex Alimentarius Commission (FAO/WHO, 2001). The Recommended Dietary Allowance (RDA) of $\mathrm{Cu}$ for proper growth and human health of an adult ranges from 1.5 to $3 \mathrm{mg} /$ day (Samira and Tawner, 2013). Copper is one of the essential micronutrients in plant metabolism. It $(\mathrm{Cu})$ is part of enzymes involved in specific metabolic processes (Tothert et al., 2016) but it could cause damage to immune system, reproductive ability, liver, neurological system and gastrointestinal tract (ATSDR, 2004).

The concentration of $\mathrm{Mn}$ in plant leaves increased from $0.11 \pm 0.00$ to $17.21 \pm 2.01 \mathrm{mg} / \mathrm{kg}$, which is relatively lower than 0.10 to $20.57 \mathrm{mg} / \mathrm{kg}$ in X. sagittifolium, T. occidentals and A. hybridus (Nduka et al., 2008) but relatively higher than $1.95 \pm 0.02$ to $15.36 \pm 0.02 \mathrm{mg} / \mathrm{kg}$ in A. hybridus, T. triangulare, $C$. papaya, I. batatas and L. aegyptiaca (Obasi et al., 2013). The concentration of Mn $(0.11 \pm 0.00$ to $17.21 \pm 2.01 \mathrm{mg} / \mathrm{kg}$ ) is well below the permissible limit of $500 \mathrm{mg} / \mathrm{kg}(\mathrm{Mn})$ set by Codex Alimentarius Commission (FAO/WHO, 2001) (Table 8). The Recommended Dietary Allowance (RDA) of Mn for proper growth and human health of an adult ranges from 2 to $5 \mathrm{mg} /$ day (Samira and Tawner, 2013). Manganese is essential element in plant metabolism and has nutritional benefit in human body. For instance, Mn play key role in photosynthetic processes in plants (Lei et al., 2007). Exposure to high dose of $\mathrm{Mn}$ affects the respiratory tract and brain of human and the symptoms include hallucinations, forgetfulness and nerve damage (Prashanth et al., 2015). The sequence of potentially toxic element in plant leaves at the fecal sludge dumpsite area was found in the order of $\mathrm{Pb}<\mathrm{Cd}<\mathrm{Cr}<\mathrm{Cu}<\mathrm{Mn}<\mathrm{Zn}$. The purpose of ranking the PTEs is to show their level of accumulation in food crops in order of concentrations.

\subsection{Pearson correlation between PTE in soil and food crops}

The result of the Pearson correlation analysis of potentially toxic elements in soil and food crops is summarized in Table 9. The result show strong positive relationship between PTE in soil and food 
crops; very strong positive relationship between PTE in soil. Emphatically, strong positive relationship exist between $\mathrm{Zn}$ in soil and food crops $(\mathrm{r}=0.616, \mathrm{p}<0.05)$ and $\mathrm{Cu}$ in soil and food crops $(\mathrm{r}=0.544, \mathrm{p}<0.05)$, which suggest that increase in $\mathrm{Zn}$ and $\mathrm{Cu}$ in soil culminated in their $(\mathrm{Zn}$ and $\mathrm{Cu})$ increase in food crops. In addition, strong positive relationship exist between $\mathrm{Zn}$ in food crops and $\mathrm{Pb}$ in soil $(\mathrm{r}=0.571, \mathrm{p}<0.05)$. More so, strong relationship occur between $\mathrm{Cu}$ in food crops and $\mathrm{Mn}$ in soil $(\mathrm{r}=0.6000, \mathrm{p}<0.05)$ and $\mathrm{Cu}$ in food crops and $\mathrm{Pb}$ in soil $(\mathrm{r}=0.560, \mathrm{p}<0.05)$. Furthermore, very strong positive relationship occur between $\mathrm{Zn}$ and $\mathrm{Cd}$ in food crops $(\mathrm{r}=0.601, \mathrm{p}<0.01), \mathrm{Zn}$ and $\mathrm{Cu}$ in food crops $(r=0.813, p<0.01), \mathrm{Zn}$ and $\mathrm{Mn}$ in food crops $(\mathrm{r}=0.770, \mathrm{p}<0.01), \mathrm{Zn}$ and $\mathrm{Cr}$ in food crops $(\mathrm{r}=0.854, \mathrm{p}<0.01), \mathrm{Zn}$ and $\mathrm{Pb}$ in food crops $(\mathrm{r}=0.661, \mathrm{p}<0.01)$. In furtherance of this, very strong positive relationship exist between $\mathrm{Cu}$ and $\mathrm{Mn}$ in food crops $(\mathrm{r}=0.959, \mathrm{p}<0.01), \mathrm{Cu}$ and $\mathrm{Cr}$ in food crops $(\mathrm{r}=0.897, \mathrm{p}<0.01), \mathrm{Cu}$ and $\mathrm{Pb}$ in food crops $(\mathrm{r}=0.890, \mathrm{p}<0.01), \mathrm{Mn}$ and $\mathrm{Cr}$ in food crops $(\mathrm{r}=$ 0.961, $\mathrm{p}<0.01), \mathrm{Mn}$ and $\mathrm{Pb}$ in food crops $(\mathrm{r}=0.886, \mathrm{p}<0.01)$ and $\mathrm{Cr}$ and $\mathrm{Pb}$ in food crops $(\mathrm{r}=0.813$, $\mathrm{p}<0.01)$. Similarly, very strong positive relationship occur between $\mathrm{Zn}$ and $\mathrm{Cd}$ in soil $(\mathrm{r}=0.966$, $\mathrm{p}<0.01), \mathrm{Zn}$ and $\mathrm{Cu}$ in soil $(\mathrm{r}=0.955, \mathrm{p}<0.01), \mathrm{Zn}$ and $\mathrm{Mn}$ in soil $(\mathrm{r}=0.955, \mathrm{p}<0.01), \mathrm{Zn}$ and $\mathrm{Cr}$ in soil $(\mathrm{r}=0.923, \mathrm{p}<0.01)$. In addition to this, very strong positive relationship exist between $\mathrm{Zn}$ and $\mathrm{Pb}$ $(\mathrm{r}=0.981, \mathrm{p}<0.01), \mathrm{Cd}$ and $\mathrm{Cu}$ in soil $(\mathrm{r}=0.942, \mathrm{p}<0.01), \mathrm{Cd}$ and $\mathrm{Mn}$ in soil $(\mathrm{r}=0.929, \mathrm{p}<0.01), \mathrm{Cd}$ and $\mathrm{Cr}$ in soil $(\mathrm{r}=0.953, \mathrm{p}<0.01), \mathrm{Cd}$ and $\mathrm{Pb}$ in soil $(\mathrm{r}=0.942, \mathrm{p}<0.01)$. Lastly, very strong positive relationship occur between $\mathrm{Cu}$ and $\mathrm{Mn}$ in soil $(\mathrm{r}=0.996, \mathrm{p}<0.01), \mathrm{Cu}$ and $\mathrm{Cr}$ in soil $(\mathrm{r}=0.982$, $\mathrm{p}<0.01), \mathrm{Cu}$ and $\mathrm{Pb}$ in soil $(\mathrm{r}=0.976, \mathrm{p}<0.01), \mathrm{Mn}$ and $\mathrm{Cr}$ in soil $(\mathrm{r}=0.971, \mathrm{p}<0.01), \mathrm{Mn}$ and $\mathrm{Pb}$ in soil $(\mathrm{r}=0.975, \mathrm{p}<0.01)$ as well as $\mathrm{Cr}$ and $\mathrm{Pb}$ in soil $(\mathrm{r}=0.942, \mathrm{p}<0.01)$.

Table 9: Correlation between heavy metals in soil and plants

\begin{tabular}{|c|c|c|c|c|c|c|c|c|c|c|c|c|}
\hline & $\begin{array}{c}\mathrm{Zn} \\
\text { (soil) }\end{array}$ & $\begin{array}{c}\mathrm{Cd} \\
\text { (soil) }\end{array}$ & $\begin{array}{c}\mathrm{Cu} \\
\text { (soil) }\end{array}$ & $\begin{array}{c}\mathrm{Mn} \\
\text { (soil) }\end{array}$ & $\begin{array}{c}\mathrm{Cr} \\
\text { (soil) }\end{array}$ & $\begin{array}{c}\mathrm{Pb} \\
\text { (soil) }\end{array}$ & $\begin{array}{c}\mathrm{Zn} \\
\text { (plant) }\end{array}$ & $\begin{array}{c}\mathrm{Cd} \\
\text { (plant) }\end{array}$ & $\begin{array}{c}\mathrm{Cu} \\
\text { (plant) }\end{array}$ & $\begin{array}{c}\mathrm{Mn} \\
\text { (plant) }\end{array}$ & $\begin{array}{c}\mathrm{Cr} \\
\text { (plant) }\end{array}$ & $\begin{array}{c}\mathrm{Pb} \\
\text { (plant) }\end{array}$ \\
\hline $\begin{array}{l}\mathrm{Zn} \\
\text { (soil) }\end{array}$ & 1 & & & & & & & & & & & \\
\hline $\begin{array}{l}\mathrm{Cd} \\
\text { (soil) }\end{array}$ & $0.966^{* *}$ & 1 & & & & & & & & & & \\
\hline $\begin{array}{l}\mathrm{Cu} \\
\text { (soil) }\end{array}$ & $0.955^{* *}$ & $0.942^{* *}$ & 1 & & & & & & & & & \\
\hline $\begin{array}{l}\text { Mn } \\
\text { (soil) }\end{array}$ & $0.955^{* *}$ & $0.929^{* *}$ & $0.996^{* * *}$ & 1 & & & & & & & & \\
\hline $\begin{array}{l}\mathrm{Cr} \\
\text { (soil) }\end{array}$ & $0.923^{* *}$ & $0.953^{* *}$ & $0.982^{* * *}$ & $0.971^{* * *}$ & 1 & & & & & & & \\
\hline $\begin{array}{l}\mathrm{Pb} \\
\text { (soil) }\end{array}$ & $0.981^{* *}$ & $0.942^{* *}$ & $0.976^{* *}$ & $0.975^{* * *}$ & $0.942^{* *}$ & 1 & & & & & & \\
\hline $\begin{array}{l}\mathrm{Zn} \\
\text { (plant) }\end{array}$ & $0.616^{*}$ & 0.414 & 0.456 & 0.500 & 0.328 & $0.571^{*}$ & 1 & & & & & \\
\hline $\begin{array}{l}\text { Cd } \\
\text { (plant) }\end{array}$ & 0.345 & 0.283 & 0.213 & 0.225 & 0.188 & 0.301 & $0.601^{* *}$ & 1 & & & & \\
\hline $\begin{array}{l}\mathrm{Cu} \\
\text { (plant) }\end{array}$ & $0.521^{*}$ & 0.320 & $0.544^{*}$ & $0.600^{*}$ & 0.425 & $0.560^{*}$ & $0.813^{* *}$ & 0.319 & 1 & & & \\
\hline $\begin{array}{l}\text { Mn } \\
\text { (plant) }\end{array}$ & 0.287 & 0.061 & 0.299 & 0.364 & 0.167 & 0.325 & $0.770^{* *}$ & 0.288 & $0.959^{* * *}$ & 1 & & \\
\hline $\begin{array}{l}\mathrm{Cr} \\
\text { (plant) }\end{array}$ & 0.231 & -0.015 & 0.170 & 0.232 & 0.021 & 0.246 & $0.854^{* *}$ & 0.412 & $0.897^{* * *}$ & $0.961^{* *}$ & 1 & \\
\hline $\begin{array}{l}\mathrm{Pb} \\
\text { (plant) }\end{array}$ & 0.313 & 0.111 & 0.360 & 0.406 & 0.232 & 0.353 & $0.661^{* *}$ & 0.094 & $0.890^{* * *}$ & $0.886^{* * *}$ & $0.813^{* *}$ & 1 \\
\hline
\end{tabular}

\subsection{Conclusions}

The study shows that potentially toxic element $(\mathrm{Cd}, \mathrm{Zn}, \mathrm{Pb}, \mathrm{Cu}, \mathrm{Cr}$ and $\mathrm{Mn})$ were present in the fecal sludge at Ubakala, Nigeria. The PTE were distributed in soil at various concentrations and assimilated at varying levels in C.papaya, T. occidentalis and M. esculenta leaves. The concentrations of the PTEs tested in dried fecal sludge were below the permitted limits established by European Union, China and Sweden. Zinc (Zn) concentration in soil is higher than the permissible limit established by Codex Alimentarius Commission while $\mathrm{Cd}$ is higher than both FAO/WHO limit and Dutch criteria for soil. The concentration of $\mathrm{Zn}$ and $\mathrm{Cr}$ in food crops is higher than the permissible limit established by the Codex Alimentarius Commission. Thus, prolong utilization of the food crops by human and animals might have serious deleterious effects on them. Strong positive relationship exist between $\mathrm{Zn}$ in soil and food crops $(\mathrm{r}=0.616, \mathrm{p}<0.05)$ and $\mathrm{Cu}$ in soil and food crops $(\mathrm{r}=0.544, \mathrm{p}<0.05)$. Very 
strong positive relationship occur between $\mathrm{Zn}$ and $\mathrm{Cd}$ in food crops $(\mathrm{r}=0.601, \mathrm{p}<0.01), \mathrm{Zn}$ and $\mathrm{Cu}$ in food crops $(\mathrm{r}=0.813, \mathrm{p}<0.01)$ while very strong positive relationship occur between $\mathrm{Zn}$ and $\mathrm{Cd}$ in soil $(\mathrm{r}=0.966, \mathrm{p}<0.01)$ and $\mathrm{Zn}$ and $\mathrm{Cu}$ in soil $(\mathrm{r}=0.955, \mathrm{p}<0.01)$. Considering the level of $\mathrm{Zn}$ and $\mathrm{Cd}$ in soil, we recommend that the fecal sludge should be treated with lime to precipitate PTE content of sludge and lowering the corresponding environmental risks.

\section{Conflict of interest}

There is no conflict of interest.

\section{References}

Abdullah, N.H., Mohamed, N., Sulaiman, L.H., Zakaria, T.A. and Rahim, D.A. (2016). Potential health impacts of bauxite mining in Kuantan. Malaysian Journal of Medical Sciences, 23(3), pp. 1-8.

Ackah, E.K. (2016). Assessment of the suitability of sludge from Dompoase faecal sludge treatment plant as a building material. A Thesis report submitted to the Department of Civil Engineering, Kwame Nkrumah University of Science and Technology for the award of degree of Master of Science (M.Sc.) in Water Supply and Environmental Sanitation, pp. 87.

Adeyeye, E.I. (2005). Distribution of major elements (Na, K, Ca, Mg) in the various anatomical parts of FADAMA crops in Ekiti State, Nigeria. Bulletin of the Chemical Society of Ethiopia, 19(2), 175183.

Agency for Toxic Substances and Disease Registry, ATSDR (2007). Toxicological Profile for Lead. U.S. Department of Health and Human Services, p. 582.

Agency for Toxic Substances and Disease Registry, ATSDR (2004). Toxicological Profile for Copper. U.S. Department of Health and Human Services, p. 272.

Ahmed, I., Ofori-Amanfo, D., Awuah, E. and Cobbold, F. (2019). A comprehensive study on the physicochemical characteristics of faecal sludge in greater Accra Region and analysis of its potential use as feedstock for green energy. Journal of Renewable Energy, 2019, pp. 1-11.

Ajah, K.C., Ademiluyi, J. and Nnaji, C.C. (2015). Spatiality, seasonality and ecological risks of heavy metals in the vicinity of a degenerate municipal central dumpsite in Enugu, Nigeria. Journal of Environmental Health Science and Engineering, 13, pp. 15-28.

Alayu, E. and Leta, S. (2020). Brewery sludge quality, agronomic importance and its short-term residual effect on soil properties. International Journal of Environmental Science and Technology, 17, pp. 2337-2348.

Al-Farraj, A.S., and Al-Wabel, M.I. (2007). Heavy metals accumulation of some plants species grown on mining area at Mahad AD'Dahab, Saudi Arabia. Journal of Applied Sciences 7: 1170-1175.

Al Hagibi, H.A., Al-Selwi, K.M., Nagi, H.M. and Al-Shwafi, N.A. (2018). Study of heavy metals contamination in mangrove sediments of the Red Sea coast of Yemen from Al-Salif to Bab-elMandeb Strait. Journal of Ecology and Natural Resources, 2(1), pp. 121-138.

Amos-Tautua, B.M.W., Onigbinde, A.O. and Ere, D. (2014). Assessment of some heavy metals and physicochemical properties in surface soils of municipal open waste dumpsite in Yenagoa, Nigeria. African Journal of Environmental Science and Technology, 8(1), pp. 4147.

Amusan, A.A., Ige, D.V. and Olawale, R. (2005). Characteristics of soils and crops uptake of metals in municipal waste dumpsites in Nigeria. Journal of Human Ecology, 17(3), pp. 167-171. 
Angelidis, M.O. and Aloupi, M. (1999). Assessment of sewage sludge quality in Greece. Toxicological and Environmental Chemistry, 68(1-2), pp. 133-139.

Anhwange, B.A. and Kaana, A. (2013). Evaluation of heavy metals in waste dumpsites. IAP Lambert Academic Publishing, Heinrich-Bocking Str. 6-8, 66121 Saarbrucken, Deutschland/Germany, pp. 154.

Antonious, G., Lobel, L., Kochhar, T., Berke, T. and Jarret, R.L. (2009). Antioxidants in C. chinense: variation among Countries Origin. Journal of Environmental Science and Health, Part B, 44 (6), pp. 621-666.

Appiah-Effah, E., Nyarko, K.B., Gyasi, S.F. and Awuah, E. (2014). Faecal sludge management in low income areas: a case study of three districts in the Ashanti Region of Ghana. Journal of Water, Sanitation and Hygiene Development, 4, pp. 189-199.

Aravind. G, Debjit, B., Duraivel, S. and Harish, G. (2013). Traditional and Medicinal Uses of Carica papaya. Journal of Medicinal Plants Studies, 1(1), pp. 7-15.

Arshad, M.A. and Coen, G.M. (1992). Characterization of soil quality: Physical and chemical criteria. American Journal of Alternative Agriculture, 7, pp. 25-31.

Awokunmi, E.E, Asaolu, S.S. and Ipinmoroti, K.O. (2010). Effect of leaching on heavy metals concentration of soil in some dumpsites. African Journal of Environmental Science and Technology, 4, pp. 495-499.

Awotoye, O.O., Ogunkunle, C.O. and Adeniyi, S.A. (2011). Assessment of soil quality under various land use practices in a humid agro-ecological zone of Nigeria. African Journal of Plant Science, 5(10), pp. 565-569.

Ayari, F., Hamdi, H.,Jedidi, N., Gharbi, N. and Kossai, R. (2010). Heavy metal distribution in soil and plant in municipal solid waste compost amended plots. International Journal of Environmental Science and Technology, 7(3), pp. 465-472.

Basalingappa, K.M., Anitha, B., Raghu, N., Gopenath, T.S., Karthikeyan, M., et al. (2018). Medicinal uses of Carica papaya. Journal of Natural and Ayurvedic Medicine, 2(6), pp. 144-154.

Bassan, M., Brdjanovic, D., Dangol, B., Dodane, P., Hooijmans, C.M., et al. (2014). Faecal sludge management systems approach for implementation and operation. Editors L. Strande, M. Ronteltap, and D. Brdjanovic. IWA PublishingAlliance House, 12 Caxton Street London SW1H 0QS, UK, pp. 1427.

Bhagure, G.R. and Mirgane, S.R. (2010). Heavy metals contaminations in groundwater and soils of Thane Region of Maharashtra, India. Environmental Monitoring and Assessment, 173(1-4), pp. 643652.

Bhat, G.P. and Surolia, N. (2001). In vitro antimalarial activity of extracts of three plants used in the traditional medicine of India. American Journal of Tropical Medicine and Hygiene, 65, 304-308.

Bhowmick, A.C., Salma, U., Siddiquee, T.A., Russel, M. and Bhoumik, N.C. (2013). Effect of temperature on the uptake of $\mathrm{Na}+, \mathrm{K}+, \mathrm{Ca} 2+$ and $\mathrm{Mg} 2+$ by the various anatomical parts of the vegetable Amaranth gangeticus. IOSR Journal of Environmental Science, Toxicology and Food Technology, 3(6), pp. 20-31.

Bożym, M. (2019). Assessment of leaching of heavy metals from landfilled foundry waste during exploitation of the heaps. Polish Journal of Environmental Studies, 28(6), pp. 4117-4126.

Brady, N.C. and Weil, R.R. (2000). The Nature and property of soils. Prentice Hall, Inc. pp. 123-127 and 506-511. 
Brummer, G. and Herms, U. (1982). Effects of accumulation of Air pollutants in Forest ecosystems, Reidel Publishing Company, pp. 233 -243.

Bu, H., Wang, W., Song, X. and Zhang, Q. (2015). Characteristics and source apportionment of dissolved trace elements in the Jinshui River of the South Qinling Mts., China. Environmental Science and Pollution Research, 22(18), pp. 14248-14257.

Carneiro, C.E. and Cruz, J.L. (2009). Caracterizaçãoanatômica de órgãosvegetativos do mamoeiro. Ciênc Rural 39(3), pp. 918-921.

Chen, T., Huang, Q.F., Gao, D., Zheng, Y.Q. Wu, J.F. (2003) Heavy metal concentrations and their decreasing trends in sewage sludges of China. Acta Scientiae Circumstantiae, 23, pp. 561-569.

Davies, B.E., (1983). A graphical estimation of the normal lead content of some British soils. Geoderma, 29, pp. 67-75.

Doran, J.W., Sarantonio, M. and Leibig, M. (1996). Soil health and sustainability. Advances in Agronomy, 56, pp. 1-54.

Elloumi, N., Belhaj, D., Jerbi, B., Zouari, M. and Kallel, M. (2016). Effects of sewage sludge on bioaccumulation of heavy metals in tomato seedlings. Spanish Journal of Agricultural Research, 14(4), pp. $1-13$.

Esakku, S., Selvam, A., Joseph, K. and Palanivelu, K. (2005) Assessment of heavy metal species in decomposed municipal solid waste. Chemical Speciation and Bioavailability, 17(3), pp. 95-102.

European Community (1986). Commission Directive No. 278. Official Journal of the European Communities, 181, pp. 5-12.

European Commission, EC (2000). DG Environment, Working Document on Sludge, 3rd Draft, Brussels. Available from: http://ec.europa.eu/environment/waste/sludge/pdf/sludge en.pdf.

European Commission Director General Environment, ECDGE (2010). Heavy Metals and Organic Compounds from Wastes Used as Organic Fertilizers. Final Rep., July. WPA Consulting Engineers $\begin{array}{lllll}\text { Inc. } & \text { Ref. } & \text { Nr. } & \text { TEND/AML/2001/07/20, } & \text { pp. }\end{array}$ http://ec.europa.eu/environment/waste/compost/pdf/hm_finalreport.pdf.

FAO/WHO (1984). List of maximum levels recommended for contaminants by the Joint FAO/WHO Codex Alimentarius Commission (3rdSeries), CAC/FAL, Rome, 3, pp. 1-8.

FAO/WHO (2001). Food additives and contaminants. Joint FAO/WHO Food Standards Program, ALINORM 01/12A, 1-289.

FAO/WHO (2006). Guidelines for assessing Quality of Herbal Medicines with Reference to Contaminants and Residues, World Health Organization, Geneva, Switzerland.

FAO/WHO (2007). Joint FAO/WHO Food Standard Programme Codex Alimentarius Commission 13th Session. Report of the Thirty Eight Session of the Codex Committee on Food Hygiene. Houston, TX, ALINORM 07/30/13.

Federal Ministry of Environment, FMEnvi Report (2002) Studies on the construction of industrial effluent treatment facilities in Kaduna.

Feng, H., Jiang, H.Y., Gao, W.S., Weinstein, M.P., Zhang, Q.F., et al. (2011). Metal contamination in sediments of the western Bohai Bay and adjacent estuaries, China. Journal of Environmental Management, 92(4), pp. 1185-1197. 
Fonge, B.A., Nkoleka, E.N., Asong, F.Z., Ajonina, S.A. and Che, V.B. (2017). Heavy metal contamination in soils from a municipal landfill, surrounded by banana plantation in the eastern flank of Mount Cameroon. African Journal of Biotechnology, 16(25), pp. 1301-1399

Funke, O.M. (2011). Evaluation of nutrient contents of Amaranth leaves prepared using different cooking methods. Food and Nutrition Sciences, 2(4), pp. 249-252.

González-Chávez, M.A., Sánchez-López, A.S. and González, R.C. (2015). Arsenic concentration in wild plants growing on two mine tailings. Pharmacognosy Communications, 5(3), pp. 197-206.

Gosslau, A. and Chen, K.Y. (2004). Nuetraceuticals, apoptosis and disease prevention. Nutrition, 20(1), pp. 95-102.

Greek legislation 80568/4225/91 of 22 March 1991 on methods, specifications and requirements for the use in agriculture of the sludge originating from household and urban waste treatment, harmonized from European Council Directive 86/278/EEC.

Gupta, S., Lakshmi, J. and Prakash, J. (2008). Effect of different blanching treatments on ascorbic acid retention in green leafy vegetables, Natural Product Radiance, 7(2), pp. 111-116.

Hashem, A. R. (2000). Microbial and mineral content of sewage sludge from Riyadh and Yanbu, Saudi Arabia. Emirates Journal of Agricultural Sciences, 12, pp. 33-41.

Huet, J., Kristin, B., Vincent, R. and Yvan, L. (2006). Structural characterization of the papaya cysteine proteinases at low pH. Biochemical and Biophysical Research Communications, 341(2), pp. 620-626.

Ideriah, J.K.T., Harry, F.O., Stanley, H.O. and Igbara, J.K. (2010). Heavy metal contamination of soils and vegetation around solid waste dumps in Port Harcourt, Nigeria. Journal of Applied Sciences and Environmental Management, 14(1), pp. 101-109.

International Agency for Research on Cancer, IARC (2006). Monographs on the evaluation of carcinogenic risks to humans, Inorganic and organic lead compounds, Lyon, France, vol. 87, p. 519.

Imaga, N.A. and Adepoju, O.A. (2010). Analyses of anti-sickling potency of Carica papaya dried leaf extract and fractions. Journal of Pharmacognosy Phytotherapy, 2(7), pp. 97-102.

Jain, M., Pal, M., Gupta, P. and Gadre, R. (2007). Effect of cadmium on chlorophyll biosynthesis and enzymes of nitrogen assimilation in greening maize leaf segments: role of 2-oxoglutarate. Indian Journal of Experimental Biology, 45(4), pp. 385-389.

Keay, R.W.J. (1959). An outlines of Nigeria vegetation. 3rd ed. Government Printer, Lagos, Nigeria.

Larson, W.E. and Pierce, F.J. (1991). Conservation and enhancement of soil quality. Evaluation for sustainable land management in the developing world, vol. 2. IBSRAM Proceedings 12, 2 Technical Papers, International Board for Soil Research and Management, Bangkok, Thailand, pp. 175-203.

Lee, Y, Lee, H.J., Lee, H.S., Jang, Y.A. and Kim, C. (2008). Analytical dietary fiber database for the National Health and Nutrition Survey in Korea. Journal of Food Composition and Analysis, 21, pp. $35-42$.

Lei, Y., Korpelainen, H. and Li, C. (2007).Physiological and biochemical responses to high Mn concentrations in two contrasting Populuscathayanapopulations. Chemosphere, 68, pp. 686-694.

Lopez Zavala, M.A. (2002). Characterization of feces for describing the aerobic biodegradation of feces. Journal of. Environ Syst. and Engineering, 720(VII-25), pp. 99-105. 
MAFF (Ministry of Agriculture, Fisheries and Food) and Welch Office Agriculture Department (1992). Code of Good Agriculture Practice for the Protection of Soil. Draft Consultation Document, MAFF, London.

Marler, T.E. and Discekici, H.M. (1997). Root development of 'Red Lady' papaya plants grown on a hillside. Plant Soil, 195(1), pp. 37-42.

Ministerial Decision Greek legislation (1991). 80568/4225/91 of 22 March 1991 on methods, specifications and requirements for the use in agriculture of the sludge originating from household and urban waste treatment, harmonized from European Council Directive 86/278/EEC, 1991.

Mtshali, J.S., Tiruneh, A.T. and Fadiran, A.O. (2014). Assessment of mobility and bioavailability of heavy metals in sewage sludge from Swaziland through speciation analysis. Resources and Environment, 4(4), pp. 190-199.

Montagnac, J.A., Davis, C.R. and Tanumihardjo, S.A. (2009). Nutritional value of cassava for use as a staple food and recent advances for improvement. Comprehensive Reviews in Food Science and Food Safety, 8, pp. 181-194.

Nduka, J.K.C., Orisakwe, O.E., Ezenweke, L.O., Chendo, M.N. and Ezenwa, T.E., et al. (2008). Heavy metal contamination of foods by refuse dump sites in Awka, Southeastern Nigeria. The Scientific World Journal, 8, pp. 941-948.

NESREA (2011). “1st Eleven Gazetted Regulations Federal Republic of Nigeria Official Gazette”.

Nkop, E.J., Ogunmolasuyi, A.M., Osezua, K.O. and Wahab, N.O. (2016). Comparative study of heavy metals in the soil around waste dump sites within University of Uyo. Archives of Applied Science Research, 8(3), pp. 11-15.

Obasi, N.A. Akubugwo, E.I., Kalu, K.M. and Ugbogu, O.C. (2013). Speciation of heavy metals and phyto-accumulation potentials of selected plants on major dumpsites in Umuahia, Abia State, Nigeria. International Journal of Current Biochemistry Research, 1(4), pp. 16-28.

Ogbonna, P.C., Odukaesieme, C. and Teixeira da Silva, J.A. (2013). Distribution of heavy metals in soil and accumulation in plants at an agricultural area of Umudike, Nigeria. Chemistry and Ecology, 29(7), pp. 595-603.

Ogbonna, P.C., Kalu, E.N. and Nwankwo, O.U. (2018a). Determination of heavy metals in sawdust particles, distribution in soil and accumulation in plants at Ahiaeke timber market. Nigerian Journal of Environmental Sciences and Technology, 2(2), pp. 160-170.

Ogbonna, P.C., Nzegbule, E.C. and Okorie, P.E. (2018b). Soil chemical characteristics in wet and dry season at Iva long wall underground mined site, Nigeria. Nigerian Journal of Environmental Sciences and Technology, 2(1), pp. 96-107.

Ogbonna, P.C., Nzegbule, E.C., Obasi, K.O. and Kalu, H. (2018c). Heavy metals in soil and accumulation in medicinal plants at an industrial area in Enyimba city, Abia State, Nigeria. Nigerian Journal of Environmental Sciences and Technology, 2(1), pp. 89-95.

Ogbonna, P.C., Osim, O.O. and Biose, E. (2020a). Determination of heavy metal contamination in soil and accumulation in Cassava (Manihot esculenta) in automobile waste dumpsite at Ohiya mechanic village. Nigerian Journal of Environmental Sciences and Technology, 4(1), pp. 54-69.

Ogbonna, P.C., Ukpai, N.P., Obasi, K.O. and Umezuruike, S.O. (2020b). Monitoring the distribution of potentially toxic elements in soil and accumulation in fodder and medicinal plant species at a quarry site in Ebonyi State, Nigeria. Nigerian Research Journal of Engineering and Environmental Sciences, 5(2) 2020 pp. 535-553. 
Okeniyi, J.A.O., Ogunlesi, T.A., Oyelami, O.A. and Adeyemi, LA. (2007). Effectiveness of dried Carica papaya against human intestinal parasitosis: A pilot study. Journal of Medicine and Food, 10(1), pp. 194-196.

Okonwu, K., Akonye, L.A. and Mensah, S.I. (2018). Nutritional composition of Telfairia occidentalis leaf grown in hydroponic and geoponic Media. Journal of Applied Sciences and Environmental Management, 22(2), pp. 259-265.

Olagunju, J., Adeneye, A., Fagbohunka, B., Bisuga, N., Ketiku, A., et al. (2009). Nephroprotective activities of the aqueous seed extract of Carica papaya Linn. In carbon tetrachloride induced renal injured Wistar rats: a dose-and time-dependent study. Biology and Medicine, 1, pp. 11-19.

Olness, A. and Archer, D. (2005). Effect of organic carbon on available water in soil. Soil Science, 170, pp. 90-101.

Olufemi, J.A., Olubunmi, S.S. and Temitope, B. (2014). Heavy metal pollution assessment of granite quarrying operations at Ikole-Ekiti, Nigeria. International Journal of Environmental Monitoring and Analysis. 2(6), pp. 333-339.

Onyedikachi, U.B., Belonwu, D.C. and Wegwu, M.O. (2018). Human health risk assessment of heavy metals in soils and commonly consumed food crops from quarry sites located at Isiagwu, Ebonyi State. Ovidius University Annals of Chemistry, 29(1), pp. 8-24.

Opaluwa, O. D., Aremu, M. O., Ogbo, L. O., Abiola, K. A., Odiba, I. E. (2012). Heavy metal concentrations in soils, plant leaves and crops grown around dump sites in Lafia Metropolis, Nasarawa State, Nigeria. Advances in Applied Science Research, 3 (2), pp. 780-784.

Otsuki, N., Dang, N.H., Kumagai, E., Kondo, A., Iwata, S. (2010). Aqueous extract of Caricapapaya leaves exhibits anti-tumor activity and immunemodulatory effects. Journal of Ethnopharmacology, 127, pp. 760-767.

Oyedele, D.J., Gasu, M.B., Awotoye, O.O. (2008). Changes in soil properties and plant uptake of heavy metals on selected municipal solid waste dump sites in Ile-Ife, Nigeria. African Journal of Environmental Science and Technology, 3(5), pp. 107-115.

Pape, P., Ayrault, S. and Cecile, Q. (2012). Trace element behavior and partition versus urbanization gradient in an urban river (Orge River, France). Journal of Hydrology, 99, pp. 472-473.

Pearson, D. (1976) Chemical Analysis of Foods. 7th Edition, Churchhill Livingstone, London.

Pitchell, J. and Anderson, M., (1997). Trace metal bioavailability in municipal solid waste and sewage sludge composts. Bioresource Technology, 60, pp. 223-229.

Pinnamaneni, R. (2017). Nutritional and medicinal value of Papaya (Carica papaya Linn). World Journal of Pharmacy and Pharmaceutical Sciences, 6(8), pp. 2559-2578.

Prashanth, L., Kattapagari, K.K., Chitturi, R.T., Baddam, V.R.R. and Prasad, L.K., et al. (2015). A review on role of essential trace elements in health and disease. Journal of NTR University of Health Sciences, 4, pp. 75-85.

Raimi, I.O., Komolafe, B.F., Agboola, O.O., Mugivhisa, L.L. and Olowoyo, J.O. (2019). Influence of wind direction on the level of trace metals in plants collected around a quarry site in South Africa. Polish Journal of Environmental Studies, 28(5), pp. 3385-3393.

Rhoades, J.D. (1996). Salinity: Electrical conductivity and total dissolved solids. In Methods of Soil Analysis: Chemical Methods. Part 3. D.L. Sparks, editor. Soil Sci. Soc. of Am., Madison WI. 
Samira, I.K. and Tawner, H.M.M. (2013), "Evaluation of heavy metals content in dietary supplements in Lebanon". Chemistry Central Journal, 7, pp. 1-12.

Santana, L.F., Inada, A.C., Santo, B.L.S.E., Filiú, W.F.O., Pott, A., et al. (2019). Nutraceutical potential of Carica papaya in metabolic syndrome. Nutrients, 11, pp. 1608-1626.

Saviozzi, A., Riffaldi, R. andCardelli, R. (1994). Suitability of a winery-sludge as soil amendment. Bioresources Technology, 49, pp. 173-178.

Shamuyarira, K.K. and Gumbo, J.R. (2014). Assessment of Heavy Metals in Municipal Sewage Sludge: A Case Study of Limpopo Province, South Africa. International Journal of Environmental Research and Public Health, 11, pp. 2569-2579.

Sikora, L. and Stott, D. (1996). Soil organic carbon and nitrogen. In: Doran W and Jones A (eds) Methods for Assessing Soil Quality, vol. 49, pp. 157-167. SSSA, Madison, WI.

Singh, A., et al. (2010). Risk assessment of heavy metal toxicity through contaminated vegetables from wastewater irrigated areas in Varanasi, India. Journal of Tropical Ecology, 51(2), pp. 375-387.

Smith, J. L. and Doran, J. W. (1996). Measurement and use of $\mathrm{pH}$ and electrical conductivity for soil quality analysis. In J. W. Doran and A. J. Jones (Eds.), Methods for assessing soil quality, pp. 169185). Madison, WI: SSSA.

Spanos, T., Ene, A., Patronidou, C.S. and Xatzixristou, C. (2016). Temporal variability of sewage sludge heavy metal content from Greek wastewater treatment plants. Ecological Chemistry and Engineering, 23(2), pp. 271-283.

Stefanakis, A.I. and Tsihrintzis, V.A. (2012). Heavy metal fate in pilot-scale sludge drying reed beds under various design and operation conditions. Journal of Hazardous Materials, 213-214, pp. 393-405.

Strande, L., Ronteltap, M. and Brdjanovic, D. (2014). Faecal sludge management: systems approach for implementation and operation, IWA Publishing. IWA Publishing, Alliance House 12 Caxton Street, London SW1H 0QS, UK.

Strauss, M., Heinss, U. and Montangero, A. (2000). On-Site Sanitation: When the pits are full Planning for esource protection in faecal sludge management. In: Proceedings, International Conference, Bad Elster, 20-24 Nov. 1998. Schriftenreihe des Vereins fuer Wasser-, Boden und Lufthygiene, 2000;105:353-60: Water, Sanitation and Health - Resolving Conflicts between Drinking Water Demands and Pressures from Society's Wastes (I. Chorus, U. Ringelband, G. Schlag, and O. Schmoll, eds.). IWA Publishing House and WHO Water Series.

Tóthert, G., Hermann, T., Da Silva, M.R. and Montanarella, L. (2016). Heavy metals in agricultural soils of the European Union with implications for food safety. Environment International, 88, pp. 299-309.

Tucker M R, Hardy D H and Stokes C E. (2005) Heavy metals in North Carolina soils: occurrence and significance. North Carolina Department of Agriculture and Consumer Services, pp. 1-2.

Udoh P, Essien I. and Udoh F. (2005). Effect of Carica papaya (paw paw) seeds extract on the morphology of pituitary-gonadal axis of male Wistar rats. Phytotherapy Research, 19, pp. 1065-1068.

UNICEF and WHO (2009). Diarrhoea: Why children are still dying and what can be done.

Varol, M., Gakot, B. and Bekleyen, A. (2013). Dissolved heavy metals in the Tigris River (Turkey): spatial and temporal variations. Environmental Science and Pollution Research, 20, pp. 6096-6108. 
Vongdala, N., Tran, H., Xuan, T.D.,Teschke, R. and Khanh, T.D. (2019). Heavy metal accumulation in water, soil, and plants of municipal solid waste landfill in Vientiane, Laos. Environmental Research and Public Health, 16(22), pp. 1-12.

Walkley, A. and Black, I.A. (1934). An examination of the Degtajareff method for soil organic matter determination and a proposed modification of the chronic acid titration. Soil Science, 37, pp. 29-38.

Wang, S. and Mulligan, C.N. (2005). Occurrence of Arsenic contamination in Canada: Sources behavior and distribution. Science of the total Environment, 366, pp. 701-721.

WHO (2006). Guidelines for the safe use of wastewater, excreta and greywater. Volume 4. Excreta and greywater use in agriculture. ISBN 9241546859.

Yeketetu, B.A. (2017). Toxic heavy metal and Salinity assessment In: Water, soil and vegetables around Meki irrigation farms. International Journal of Scientific and Technology Research, 6(9), pp. $5-10$.

Zziwa, A., Nabulime, M.N., Kiggundu, N., Kambugu, R., Katimbo, A. et al. (2016). A critical analysis of physiochemical properties influencing pit latrine emptying and feacal sludge disposal in Kampala Slums, Uganda. African Journal of Environmental Science and Technology, 10(10), PP. 316-328.

Cite this article as:

Ogbonna P. C., Okezie I. P., Onyeizu U. R., Biose E., Nwankwo O. U. and Osuagwu E. M. 2021. Analysis of Soil Quality Status and Accumulation of Potentially Toxic Element in Food Crops Growing at Fecal Sludge Dumpsite in Ubakala, Nigeria.Nigerian Journal of Environmental Sciences and Technology, 5(1), pp. 197-221. https://doi.org/10.36263/nijest.2021.01.0273 